\title{
Policy-Induced Expansion of Solar and Wind Power Capacity: Economic Growth and Employment in EU Countries
}

\author{
Jūratè Jaraitè, ${ }^{\text {a* }}$ Amin Karimu, ${ }^{\mathrm{a}}$ and Andrius Kažukauskas ${ }^{\mathrm{a}}$
}

\begin{abstract}
Given the intensifying debates on whether governments should promote particular renewable energy technologies, the main objective of this study is to investigate the long- and short-run effects of policy-induced expansion of renewable solar and wind technologies on economic growth and employment in 15 European Union (EU) member states during 1990-2013 by using panel-data time-series econometric techniques. Instead of relying on renewable energy consumption or generation as commonly done in the literature, we focus on the capacity for solar and wind power generation, which is largely a consequence of the EU's renewable energy policies. In summary, we find that, to date, renewable energy policyinduced wind and solar power capacity promotes growth and/or employment in the short run, but these capacity increases do not stimulate economic growth in the long run in the EU-15 region. In fact, our results tend to support the opposite relationship: increases in wind and solar power capacity are associated with negative economic growth, at least at the total economy level.
\end{abstract}

Keywords: Economic growth, Employment, European Union, Granger causality, Panel cointegration, Policy, Renewable energy capacity, Solar energy, Wind energy

https://doi.org/10.5547/01956574.38.5.jjar

\section{INTRODUCTION}

The role of renewable energy is gradually increasing in modern economic and social development. Over the last couple of decades, the deployment and use of renewable energy sources (RES) have been growing significantly worldwide. The share of renewable electricity generation in the global electricity mix increased from 18 per cent in 2007 to almost 22 per cent in 2013 (IEA, 2014). Worldwide, renewable electricity generation is now on par with that of natural gas. In 2013, renewable electricity generation accounted for more than 27 per cent of total gross electricity generation in the European Union (EU), almost twice the figure for 2005 (Eurostat, 2015).

This expansion of renewable energy in the EU would be impossible without support from policy makers. For a long time, several EU member states have stimulated renewable energy production through various funding schemes, yet it was not until the early 1990s that promotional

a Centre for Environmental and Resource Economics (CERE), School of Business and Economics, Department of Economics, Umeå University, Biblioteksgränd 6, SE-90187, Umeå, Sweden.

* Corresponding author. E-mail: jurate.jaraite@umu.se.

Note that the earlier version of this paper is available as a CERE working paper (http://www.cere.se/documents/wp/ 2015/CERE_WP2015-7.pdf). 
programs really picked up the speed across the EU (Haas et al., 2011). ${ }^{1}$ Since then, subsidies to renewable energy have been growing rapidly in many EU countries. For instance, in Germany they increased from EUR 9.5 billion in 2010 to EUR 12.7 billion in 2012, and in Spain from EUR 5.4 billion to EUR 8.4 billion in the same period (European Commission, 2014).

From an economics perspective, only a mix of three externalities, namely environmental externalities, energy security and promotion of learning-by-doing (or knowledge spillovers), can justify the strong support for renewable energy expansion (Canton and Johannesson Lindén, 2010). In the EU, the negative externality of climate change (one of the environmental externalities) has been to some extent addressed by the EU's Emission Trading System and other national climate change programs. Thus, the remaining key justification ${ }^{2}$ for subsidizing renewable energy is learning-by-doing effects. The policy-driven higher demand for renewable electricity is supposed to stimulate particular industries, such as manufacturing of wind turbines and solar PV modules, through a scale effect. The main idea of the scale effect is that with the mass production of renewable energy technologies comes a reduction in marginal costs of producing, say, an additional wind turbine or a solar PV module. This means that every firm in e.g. manufacturing of wind turbines benefits both from its own investments and from the whole industry's increased knowledge from learning-by-doing.

The case of wind and solar energy exemplifies that the costs of producing renewable energy technologies are decreasing in both scale and increasing market experience. Figure A in the appendix shows the relationship between the historical cumulative capacity of wind turbines and solar PV modules and the costs per unit of installed capacity. It is evident that over the last 20 years, the cumulative capacity of solar PV modules and wind turbines has been steadily growing, while the costs of the respective renewable energy capacity has been sharply decreasing, especially in the last few years. With additional economic incentives from policy makers, the cost of producing wind turbines and solar PV modules is expected to continue to fall (Wagner et al., 2015).

However, the implementation of industrial and innovation policies, which can be defined as attempts by governments to promote growth of particular industrial sectors, remains controversial. For example, the Economist's article Picking Winners, Saving Losers criticizes increasing subsidies to promote certain green technologies, warning that 'picking industrial winners nearly always fails' (The Economist, 2010). Indisputably, renewable energy helps to mitigate climate change and increases energy security and diversification for countries that are net energy importers. However, the net economic effects of increasing renewable energy on economic growth and employment are ambiguous and subject to empirical and modelling scrutiny. As discussed by Lehr, Lutz and Edler (2012), in the short run, the gross effect of increasing investments in renewable energy sources on economic activity and employment in RES-related industries is obviously positive. ${ }^{3}$ This argument is usually highlighted by policy makers when promoting the development of

1. See Haas et al. (2011) for a historical review of promotion strategies for electricity from renewable energy sources in EU countries.

2. In this study, we consider energy security objective less important since, according to Canton and Johannesson Lindén (2010) conclusions, which are based on their literature review, the benefits of increased energy security seem to be quite modest.

3. In the EU, the number of jobs has been successively growing over the last years, and is expected to grow further. The first report of EmployRES project estimated gross employment in RES up to 2.8 million jobs in EU27 in 2020 and 3.4 million employees by 2030, while the net employment effect of renewable policy (taking into account job losses in other sectors) is forecasted to range between 200,000 and 400,000 new jobs (Ragwitz et al., 2009). In 2050, the modelling estimates of gross and net employment in the EU28 are 2.3 million jobs and 1.4 million jobs, respectively Duscha et al. (2014).

Copyright (C) 2017 by the IAEE. All rights reserved. 
renewable energy. However, in both the long run and short run, these positive short-run effects might be diminished or even offset by negative impacts originating from two sources: first, green energy investments might crowd out investments in other potentially more productive conventional energy sectors; second, renewable energy, at least initially, translates into additional energy costs for households and firms. This reduces their expenditure in other sectors, resulting in lower output and fewer jobs in those sectors.

Given the intensifying debates on whether governments should promote certain renewable energy technologies, the main objective of the present study is to investigate the effects of policyinduced expansion of renewable electricity-generating capacity on economic growth and employment in 15 European Union member states (EU-15) in the 1990-2013 period by using panel-data time-series econometric techniques. In particular, the paper aims to expand the existing literature in the following three unexplored directions.

First, this study focuses on the rather, development-wise, homogenous EU-15 region. EU15 has promoted renewable energy for a long time and is also the most coordinated region in terms of renewable energy policies. This makes it a well-suited case for examining the effects of policyinduced changes in renewable electricity-generating capacity. The Renewable Energy Directive (European Parliament and Council, 2009) requires the EU to meet at least 20 per cent of its total energy needs with renewables by 2020 - to be achieved through the attainment of individual national targets. EU member states are free to choose their own measures to meet their individual obligations. This has resulted in a number of different policies, including feed-in tariffs, tradable green certificate systems, tax breaks and investment subsidies. Furthermore, our interest in the EU region is determined by another two reasons. The first one is that the expansion of wind and solar power generation would be unlikely without support from EU policy makers since solar and wind energy has been and remains uncompetitive relative to conventional energy. The second reason, as discussed above, is that learning-by-doing is the key economic and political justification for the current EU renewable policies.

Second, instead of looking at total renewable energy consumption or generation, as done in earlier similar empirical studies on the renewable energy-economic growth nexus (see our literature review in Section 2), we focus on wind and solar electricity generating capacity. ${ }^{5}$ The rationale for using capacity instead of consumption is that capacity is better suited for comparing the efforts of renewable energy policies to enhance the technological advancement through learningby-doing effects. Renewable energy capacity utilization (production) levels differ a lot across EU member states. The presence of high volatility in capacity utilization data, mainly because of weather and other factors, makes it difficult to capture slow changing output gains due to learningby-doing and other technological advancement effects. For example, in Ireland, due to mostly weather related conditions, the capacity factor for wind generation varied from 24 per cent to 35 per cent (EirGrid and SONI, 2015). We argue that this makes renewable energy consumption/

4. The term EU-15 refers to the 15 member states of the European Union as of 31 December 2003, before the new member states joined the EU. The 15 member states are Austria, Belgium, Denmark, Finland, France, Germany, Greece, Ireland, Italy, Luxembourg, Netherlands, Portugal, Spain, Sweden and the United Kingdom.

5. We understand that renewable energy policies are not limited to solar and wind, and therefore our capacity variables might not capture all learning-by-doing effects induced by the EU's renewable energy policies. Nevertheless, solar and wind energy are the leading renewable energy sources and are attracting the greatest interest among policy makers and in the industry, at least at EU level. Additionally, solar and wind energy has been and remains uncompetitive relative to conventional energy sources without the additional support from governments. 
generation data inadequate for studying learning-by-doing and scale effects in related manufacturing sectors.

The last contribution of our study is that we perform our analysis at three different data aggregation levels to understand the effects of solar and wind energy capacity expansion not only on the overall economy, but also on total manufacturing and the sector of manufacturing of machinery and equipment that includes manufacturing of solar and wind energy technologies. By performing the analysis at three different levels of economic activity, we will be able to provide more insights about the economic effects of policy-induced expansion of the capacity to produce renewable energy on the EU economy.

The main hypotheses of this study are that the EU's policy-induced renewable electricitygenerating capacity leads to (1) technological advancement, followed by economic growth, in the long run and to (2) increased economic growth and employment in the short run. In summary, our results support the hypothesis that renewable energy policy-induced wind and solar capacity promotes growth and/or employment in the short run, but not the hypothesis that these capacity changes promote growth and possibly the associated employment effect in the long run. Instead, our results support the opposite relationship: to date, changes in wind and solar power capacity are associated with negative economic growth in the EU-15 region.

The remainder of the paper is organized as follows: Section 2 provides a short summary and a discussion of the relevant literature on the renewable energy-economic growth nexus. Section 3 presents our empirical framework. Section 4 describes the data and its sources. Section 5 contains the empirical results. A short summary and some concluding remarks are presented in the final section.

\section{BRIEF LITERATURE REVIEW}

The renewable energy-economic growth nexus has been studied rather intensively for over a decade. This surge in interest can partly be attributed to the focus of policy makers on promoting renewable energy worldwide. Another reason is that advances in time-series and panel-data econometric techniques as well as the availability of long data series have made researchers better able to investigate this issue for various countries and regions. A recent study by Sebri (2015) synthesizes the empirical literature on this topic using a meta-analysis approach and finds that the variation in the results is due to a number of characteristics, including model specification, data characteristics, estimation techniques and the country's level of development.

Below we summarize some of the results from 16 empirical studies that used time-series and panel-data econometric techniques to analyze the renewable energy-economic growth nexus for EU countries or a group of countries that includes at least one EU country. Table 1 summarizes the selected studies in terms of geographical scope, time period studied, definitions of the renewable energy variable, long-run elasticities computed using the panel cointegration techniques, existence of causality from renewable energy to economic growth and causality from renewable energy to total employment.

Only Menegaki (2011) and Ucan, Aricioglu and Yucel (2014) analyze the renewable energy-economic growth nexus for EU countries. The other studies focus either on OECD countries or a mix of developed and developing/emerging countries. Most studies analyze 20-30 years of historical data, from as early as 1980 to as late as 2012. In this respect, our study is not different as it uses 23 years of data.

The selected studies use different definitions of renewable energy variables. Most of them include total renewable energy consumption or net renewable energy consumption (see e.g. Sa- 


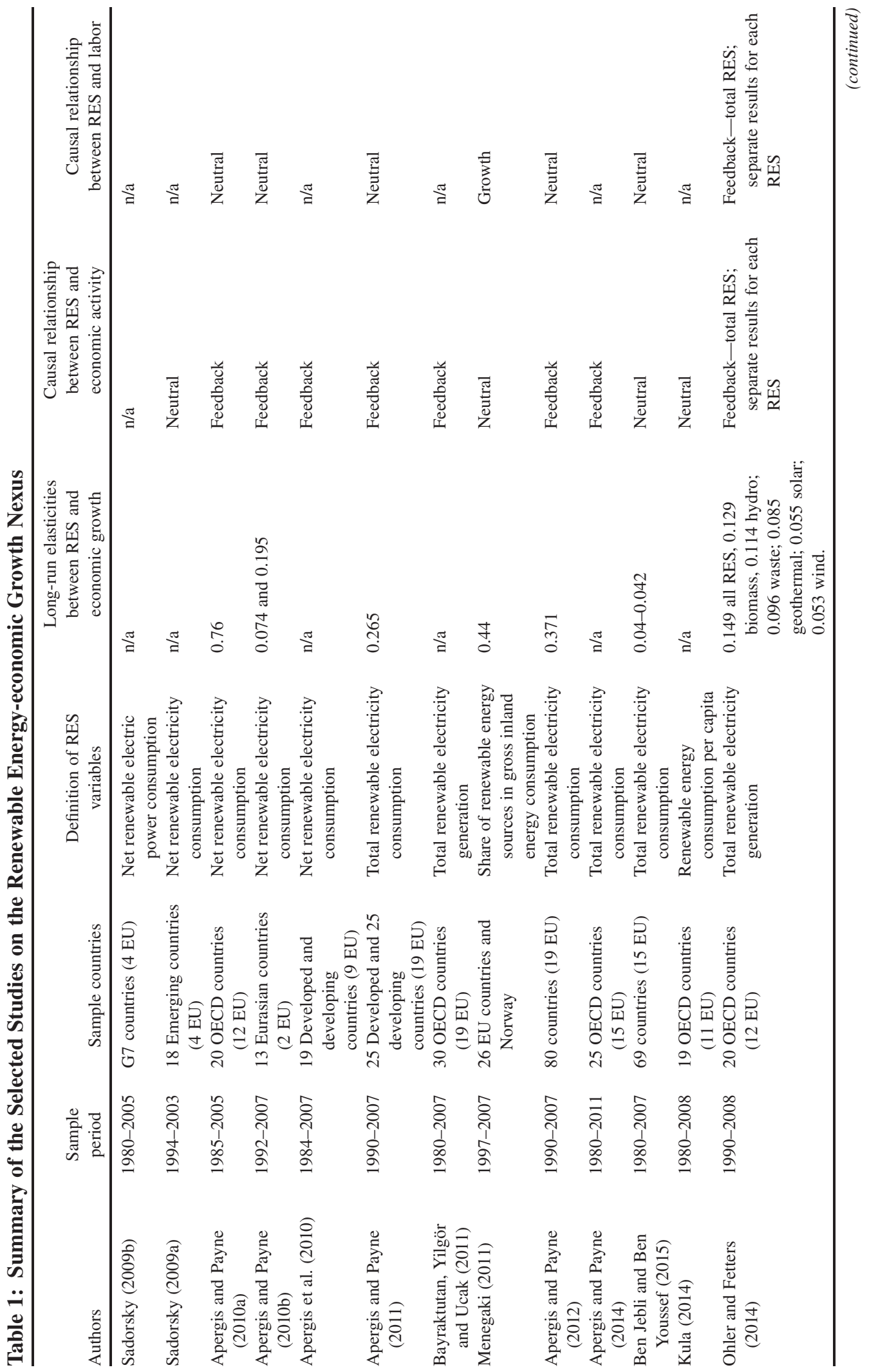




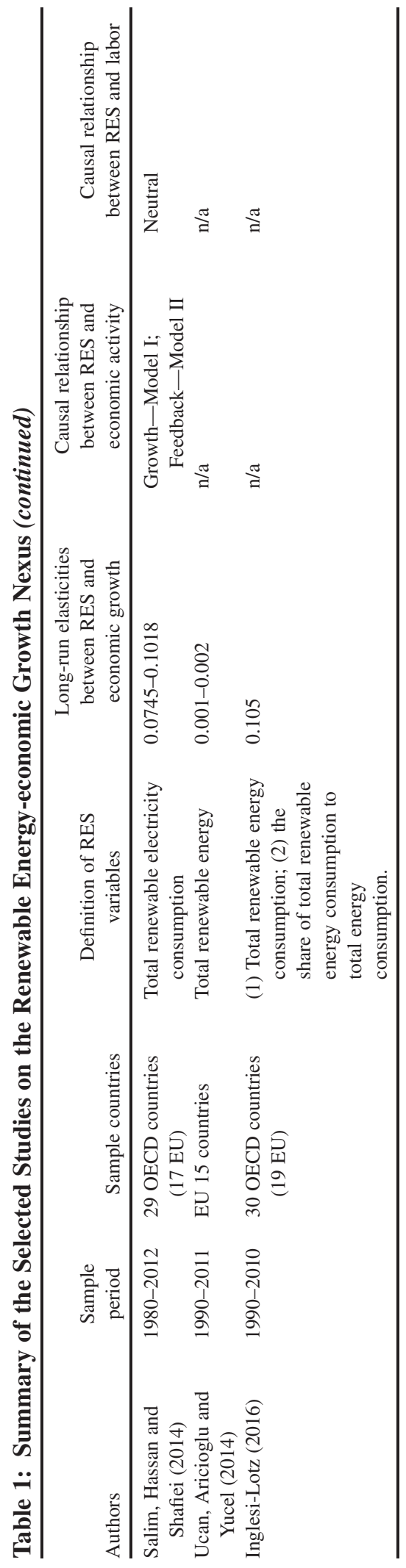

Copyright (C) 2017 by the IAEE. All rights reserved. 
dorsky (2009b). Net consumption does not include the energy consumed by the generating units. Bayraktutan, Yilgör and Ucak (2011) and Ohler and Fetters (2014) use renewable electricity generation. A few papers use ratio variables such as the share of total renewable energy consumption to total energy consumption (Inglesi-Lotz, 2016, Menegaki, 2011) and renewable energy consumption per capita (Kula, 2014). Ucan, Aricioglu and Yucel (2014) provide very little information about their renewable energy variable.

Ten of the 16 selected studies report long-run elasticities computed using panel cointegration techniques. The reported coefficients are positive and statistically significant and range from 0.001 to 0.76 . These results indicate that a one per cent increase in renewable energy consumption leads to a 0.001 to 0.76 per cent increase in economic growth, which in most studies is measured as a change in real GDP. The study by Ohler and Fetters (2014) differs from the other selected studies in that it estimates the long-run elasticities across 20 OECD countries 1990-2008 for each renewable energy source: biomass, geothermal, hydroelectricity, solar, waste and wind. All estimated coefficients are positive and statistically significant. A one per cent increase in biomass increases real GDP by 0.129 per cent. For hydroelectricity and waste generation, the corresponding increase is 0.1114 per cent and 0.096 per cent, respectively. Geothermal, solar and wind have the smallest impact on real GDP, with estimated long-run elasticities of $0.085,0.055$ and 0.053 , respectively.

Most studies on the causal dynamics find support for the feedback hypothesis implying that there is bidirectional causality between renewable energy and economic growth, i.e. both variables influence each other. Only four selected studies find a lack of causality between renewable energy and economic growth. Ohler and Fetters (2014) disaggregate renewable energy sources and examine the causal relationship between each renewable energy source and economic activity. Interestingly, geothermal and wind energy both exhibit negative bidirectional causality with real GDP, while hydroelectricity and waste energy positively contribute to real GDP.

Finally, we are interested in whether renewable energy increases employment. This question is not explicitly considered in our selected studies, but a few of them do include total employment as an important factor of economic activity and examine the causal relationship between renewable energy and employment. Six of the eight studies that consider employment find no support for causality between renewable energy and employment, while the remaining two (Menegaki, 2011, Ohler and Fetters, 2014) find that renewable energy contributes to employment. Ohler and Fetters (2014) analyze this relationship for each renewable energy source and find that biomass, hydro and wind power support employment.

Unlike the previous studies summarized above, the present paper aims to expand the existing literature in the following unexplored directions. First of all, this study focuses on the EU15 region, which has had consistent renewable energy support policies for many years. Secondly, instead of using total renewable electricity consumption or generation, we use the installed capacity of solar and wind energy generation. Thirdly, we disaggregate the data to understand the effects of increased solar and wind energy generating capacity not only on the total economy but also on total manufacturing and the sector of manufacturing of machinery and equipment that includes manufacturing of solar and wind energy technologies.

\section{EMPIRICAL FRAMEWORK}

Similar to previous research discussed in Section 2, the present study augments the neoclassical Cobb-Douglas production function by incorporating energy in addition to capital and labor 
inputs. In particular, our model contains four explanatory variables: capital, labor, total energy consumption and state of technology.

Generally, the production function can be written as

$$
Y_{i t}=f\left(K_{i t}, L_{i t}, E C_{i t}, A_{i t}\right)
$$

where $Y_{i t}$ represents the aggregate output at time $t$ for country $i, K_{i t}$ is capital stock, $L_{i t}$ is labour, $E C_{i t}$ is the economy's energy consumption and $A_{i t}$ is the state of technology. $A_{i t}$ is assumed to be a function of three variables,

$$
A_{i t}=\left(S O L_{i t}, W N D_{i t}, T C_{i t}\right)
$$

where $S O L_{i t}$ and $W N D_{i t}$ denote the policy-driven capacity for production of renewable energy ${ }^{6}$, namely solar and wind, through learning-by-doing at time $t$ for country $i$, and $T C_{i t}$ is other exogenous technological changes.

Consequently, the following log-linear reduced form of an aggregate Cobb-Douglas production function is used to investigate the long-run and short-term relationships between economic activity, employment and RES policy-induced changes in wind and solar capacity:

$$
\ln Y_{i t}=\alpha \ln K_{i t}+\beta \ln L_{i t}+\gamma \ln E C_{i t}+\delta \ln S O L_{i t}+\theta \ln W N D_{i t}+\vartheta T C_{i t}+e_{i t}
$$

$\alpha, \beta, \gamma, \delta$ and $\theta$ are the elasticities of output with respect to capital, labor, total energy consumption, solar power capacity and wind power capacity, respectively, which will be estimated using the data, and $e_{i t}$ denotes the error term.

To deepen our analysis, we estimate Eq. (3) at three aggregation levels: (1) total economy, (2) total manufacturing and (3) manufacturing of machinery and equipment that includes manufacturing of renewable energy technologies. Consequently, three different models are estimated:

Model 1: Output $($ Total economy $)=f($ total economy capital $(\mathrm{K})$, total economy labor $(\mathrm{L})$, total economy energy consumption (EC), solar power capacity (SOL), wind power capacity (WND));

Model 2: Output (Manufacturing) $=f$ (manufacturing capital $(\mathrm{K})$, manufacturing labor $(\mathrm{L})$, manufacturing energy consumption (EC), solar power capacity (SOL), wind power capacity (WND)); and

Model 3: Output (Machinery) $=f($ machinery capital $(\mathrm{K})$, machinery labor $(\mathrm{L})$, machinery energy consumption (EC), solar power capacity (SOL), wind power capacity (WND)).

In our study we test and discuss two key hypotheses. The first hypothesis is based on the assumption that the expansion of renewable energy capacity through subsidies brings technological improvements through learning-by-doing and substantial benefits in terms of economic growth in

6. Here we make a credible assumption that the rapid expansion of wind and solar power generating capacity in the rich EU member states would be impossible without support from policy makers, because wind and solar power are uncompetitive relative to conventional energy sources in the EU region. 
the long run. After decades of significant support to wind and solar electricity generation capacity across the EU countries, one might expect these policy efforts to bear fruit, in particular in sectors involved in the production of renewable energy technologies.

Hypothesis 1: The capacity changes in wind and solar power generation induced by the EU's renewable energy support policy led to technological advancement followed by economic growth in the long run.

Politicians advocating for renewable energy expansion have been claiming that these types of policy-induced changes generate not only economic growth in the long run but also employment and output growth in the short run. Therefore, our second hypothesis is that:

Hypothesis 2: The capacity changes in wind and solar power generation induced by the EU's renewable energy policy increase output and employment in the short run.

We test the defined hypotheses by estimating the model in Eq. (3) and by using homogeneous (fixed effect, FE) and heterogeneous estimators, i.e. Pesaran and Smith's (1995) mean group estimator (MG), Pesaran's (2006) common correlated mean group estimator (CCMG) and Eberhardt and Teal (2010) augmented mean group estimator (AMG). Our empirical approach follows three steps. First, we use a unit root test to determine the time series properties of the data. Second, we use a cross-sectional dependency test to determine whether the unobserved common factors need to be corrected for in the estimation process for our long-run model. Third, we use a causality analysis to determine the causal dynamics and test our two hypotheses.

Estimating Eq. (3) based on the usual panel estimators such as a fixed-effect model in a situation where unobserved common factors are correlated with the included covariates and vary across countries and time might result in biased estimates. To appropriately account for unobserved common factors, we apply an econometric modelling approach based on the 'unobserved common factor framework' that will account for unobserved factors including spillovers on the estimated parameters of interest. The approach is briefly presented below, where we for ease of exposition define $x_{i t}^{\prime}$ as a vector of all covariates as specified in Eq. (3).

$$
\begin{aligned}
& y_{i t}^{s}=\beta_{i}^{s} x_{i t}^{\prime s}+u_{i t}^{s} \\
& u_{i t}^{s}=\alpha_{1 i}^{s}+\varphi_{i}^{s} f_{t}^{s}+u_{i t}^{s}+e_{i t}^{s} \\
& x_{i t}^{s}=\alpha_{2 i}^{s}+\varphi_{i}^{s} f_{i}^{s}+\gamma_{i}^{s} g_{t}^{s}+v_{i t}^{s}
\end{aligned}
$$

$x_{i t}^{\prime s}$ is a vector of the explanatory variables, $v_{i t}^{s}$ and $e_{i t}^{s}$ are the stochastic error terms, $f_{t}^{s}$ and $g_{t}^{s}$ are the unobserved common factors with heterogeneous factor loading parameters ${ }^{7} \varphi_{i}^{s}$ and $\gamma_{i}^{s}$, respectively. The country's fixed effect is denoted $\alpha_{1 i}^{s}$, which captures time-invariant heterogeneity across panel units. We assume that latent processes drive both the dependent variable via Eq. (5) and the vector of explanatory variables via Eq. (6), where $\phi_{i}^{s}$ and $\gamma_{i}^{s}$ are the latent factor loading

7. These will capture the effect of factors such as the financial crisis and slowdown of the world economy. The potential effect of these factors on output is modelled such that, the effects vary from country to country, rather than assuming the same effect for all countries. 
parameters that vary across panel units. If on average the factor loading parameters are zero (this will happen only if the effect of unobserved common factors, such as the financial crisis and slowdown of the world economy, on the included variables for the analysis are insignificant), then the usual panel data estimators, such as a fixed effect, produce consistent and unbiased estimates for the parameter vector $\beta^{s}$, if the assumption that $\beta_{i}^{s}=\beta^{s}$ holds. However, if on average the factor loading parameters are not zero, then the usual panel estimators will be biased and inconsistent, as shown in Eberhardt, Helmers and Strauss (2013).

The relationships captured by Eq. (4) to (6) are summarized as follows: first Eq. (4) shows that output $\left(y_{i t}^{s}\right)$ depends on input and policy vector $\left(x_{i t}^{\prime s}\right.$, which includes capital, labour, total energy consumption, solar power capacity and wind power capacity) and a composite error term $\left(u_{i t}^{s}\right)$. Eq. (5) relates the composite error to its constituent parts, a country fixed effect, unobserved common factors $\left(f_{t}^{s}\right)$, such as the financial crisis, and a pure random noise $\left(e_{i t}^{s}\right)$. Eq. (6) relates the input and policy vector to general unobserved common factors $\left(f_{t}^{s}\right)$, unobserved factors that only affect the inputs and policy vector $\left(g_{t}^{s}\right)$ and a pure random noise $\left(v_{i t}^{s}\right)$.

The expressions in Eq. (4)-(6) are estimated for each panel unit and the average panel coefficient for $x_{i t}^{\prime s}$ is calculated as $N^{-1} \sum_{i=1}^{N} \beta_{i t}^{s}=\beta^{s}$, hence given a long time period we can have estimates for each panel unit as well as the average over all panel units in order to assess whether the parameters vary across countries. However, in a panel with a short time period, it is important to report only the average panel coefficients since the individual panel estimates are likely to be imprecise due to the low degree of freedom. Details on the unobserved common factor framework can be found in Pesaran (2006) and Kapetanios, Pesaran and Yamagata (2011). Both the CCMG and AMG estimators are designed based on the unobserved common factor framework as described above, while the MG estimator is not (it only relaxes the homogeneous slope coefficient assumption and does not account for unobserved common factors). The MG approach allows for heterogeneity across panel units by making both the slope coefficients and the error variances vary across panels units. Yet it does not incorporate information on unobserved common factors that might be present in the data. The CCMG model corrects for unobserved common factors by including the crosssectional averages of the dependent and independent covariates as additional regressors. The idea is to strip off all (potentially) unobserved common factor effects from the estimates of interest via the included cross-sectional averages. The AMG approach is an alternative to the CCMG and was developed by Eberhardt and Teal (2010). The only difference between the AMG and the CCMG is in how the correction is done for the unobserved common factors. In the CCMG approach the correction parameters are treated as nuisance, whereas in the case of the AMG estimator they are treated as a common dynamic process that can have a useful interpretation. Our interest here is to allow the data-generating process to inform the choice of estimator by implementing various panel estimators with different underlying assumptions, such as fixed versus varying parameters and accommodating latent common factors or not. The selection of estimator is then made based on the diagnostics, specifically both stationary and cross-sectional independent residuals. This is to ensure results that are free from spurious regression and cofounding effects of unobserved common factors that could bias the estimates.

The causal analysis is done based on the Granger methodology. We propose to account for both short-run and long-run causality via an error correction framework, while at the same time allowing for parameter heterogeneity in the testing procedure. The causality relationships are examined based on a panel error correction model by taking a first difference of each variable as a function of a lagged difference of each covariate and an error correction term as expressed below: 


$$
\begin{aligned}
& \Delta y_{i t}^{s}=\alpha_{1 i}^{s}+\sum_{k=1}^{q} \phi_{11 i k}^{s} \Delta y_{i t-k}^{s}+\sum_{k=1}^{q} \phi_{12 i k}^{s} \Delta k_{i t-k}^{s}+\sum_{k=1}^{q} \phi_{13 i k}^{s} \Delta l_{i t-k}^{s}+\sum_{k=1}^{q} \phi_{14 i k}^{s} \Delta e c_{i t-k}^{s} \\
& +\sum_{k=1}^{q} \phi_{15 i k}^{s} \Delta s o l_{i t-k}^{s}+\sum_{k=1}^{q} \phi_{16 i k}^{s} \Delta w n d_{i t-k}^{s}+\eta_{1 i}^{s} e_{i t-1}^{s}+v_{1 i t}^{s}, \\
& \Delta k_{i t}^{s}=\alpha_{2 i}^{s}+\sum_{k=1}^{q} \phi_{21 i k}^{s} \Delta y_{i t-k}^{s}+\sum_{k=1}^{q} \phi_{22 i k}^{s} \Delta k_{i t-k}^{s}+\sum_{k=1}^{q} \phi_{23 i k}^{s} \Delta l_{i t-k}^{s}+\sum_{k=1}^{q} \phi_{24 i k}^{s} \Delta e c_{i t-k}^{s} \\
& +\sum_{k=1}^{q} \phi_{25 i k}^{s} \Delta s o l_{i t-k}^{s}+\sum_{k=1}^{q} \phi_{26 i k}^{s} \Delta w n d_{i t-k}^{s}+\eta_{2 i}^{s} e_{i t-1}^{s}+v_{2 i t}^{s}, \\
& \Delta l_{i t}^{s}=\alpha_{3 i}^{s}+\sum_{k=1}^{q} \phi_{31 i k}^{s} \Delta y_{i t-k}^{s}+\sum_{k=1}^{q} \phi_{32 i k}^{s} \Delta k_{i t-k}^{s}+\sum_{k=1}^{q} \phi_{33 i k}^{s} \Delta l_{i t-k}^{s}+\sum_{k=1}^{q} \phi_{34 i k}^{s} \Delta e c_{i t-k}^{s} \\
& +\sum_{k=1}^{q} \phi_{35 i k}^{s} \Delta s o l_{i t-k}^{s}+\sum_{k=1}^{q} \phi_{36 i k}^{s} \Delta w n d_{i t-k}^{s}+\eta_{3 i}^{s} e_{i t-1}^{s}+v_{3 i t}^{s}, \\
& \Delta e c_{i t}^{s}=\alpha_{4 i}^{s}+\sum_{k=1}^{q} \phi_{41 i k}^{s} \Delta y_{i t-k}^{s}+\sum_{k=1}^{q} \phi_{42 i k}^{s} \Delta k_{i t-k}^{s}+\sum_{k=1}^{q} \phi_{43 i k}^{s} \Delta l_{i t-k}^{s}+\sum_{k=1}^{q} \phi_{44 i k}^{s} \Delta e c_{i t-k}^{s} \\
& +\sum_{k=1}^{q} \phi_{45 i k}^{s} \Delta s o l_{i t-k}^{s}+\sum_{k=1}^{q} \phi_{46 i k}^{s} \Delta w n d_{i t-k}^{s}+\eta_{4 i}^{s} e_{i t-1}^{s}+v_{4 i t}^{s}, \\
& \Delta s o l_{i t}^{s}=\alpha_{5 i}^{s}+\sum_{k=1}^{q} \phi_{51 i k}^{s} \Delta y_{i t-k}^{s}+\sum_{k=1}^{q} \phi_{52 i k}^{s} \Delta k_{i t-k}^{s}+\sum_{k=1}^{q} \phi_{53 i k}^{s} \Delta l_{i t-k}^{s}+\sum_{k=1}^{q} \phi_{54 i k}^{s} \Delta e c_{i t-k}^{s} \\
& +\sum_{k=1}^{q} \phi_{55 i k}^{s} \Delta s o l_{i t-k}^{s}+\sum_{k=1}^{q} \phi_{56 i k}^{s} \Delta w n d_{i t-k}^{s}+\eta_{5 i}^{s} e_{i t-1}^{s}+v_{5 i t}^{s},
\end{aligned}
$$

$$
\begin{aligned}
\Delta w n d_{i t}^{s} & =\alpha_{6 i}^{s}+\sum_{k=1}^{q} \phi_{61 i k}^{s} \Delta y_{i t-k}^{s}+\sum_{k=1}^{q} \phi_{62 i k}^{s} \Delta k_{i t-k}^{s}+\sum_{k=1}^{q} \phi_{63 i k}^{s} \Delta l_{i t-k}^{s} \\
& +\sum_{k=1}^{q} \phi_{64 i k}^{s} \Delta e c_{i t-k}^{s}+\sum_{k=1}^{q} \phi_{65 i k}^{s} \Delta s o l_{i t-k}^{s}+\sum_{k=1}^{q} \phi_{66 i k}^{s} \Delta w n d_{i t-k}^{s}+\eta_{6 i}^{s} e_{i t-1}^{s}+v_{6 i t}^{s},
\end{aligned}
$$

where $s$ denotes the level of data aggregation, $k=1, \ldots, q$ represents the lag length, $\Phi$ are the shortrun coefficients, $e_{i t-1}$ denote the lagged error terms from the long-run model and therefore the error correction term and $v_{i t}$ are the random error terms for the short-run model. Eq. (7a) to (7f) are a system of equations that involves all the variables in our Cobb-Douglas production function, namely output, capital, labor, energy consumption, solar power capacity and wind power capacity. The variables are expressed as growth rates in order to account for short-run causal analysis. In Eq. (7a), growth in output is regressed on its previous value, current and previous values of each of the other variables, and an error correction term $\left(e_{i t-1}^{s}\right)$ to test for long-run causality. The previous terms of output and each of the other variables are to capture the adjustment process in the estimation. 
Moving from Eq. (7a) to Eq. (7f) entails replacing output as the dependent variable by each of the other variables sequentially.

We test short-run causality for each of the variables via the null hypothesis $H_{0}$ : each $\phi_{m n i k}^{s}=0$. The null hypothesis means that the estimated coefficient $\phi_{m n i k}^{s}$ is not statistically different from zero, implying it has no effect on the estimated model. For instance in Eq. (7a), to test whether capital causes output in the short-run is to test the null hypothesis that $\phi_{12 i k}^{s}=0$. The long-run causality is tested via the null hypothesis $H_{0}$ : each $\eta_{m i}^{s}=0 . m$ indexes the equation number in the vector of equations and $n$ indexes the coefficient for each of the variables in the equation.

\section{DATA}

The annual data for a set of EU-15 member states covering the period 1990-2013 is collected from Eurostat in September 2015. This gives us a panel of up to 360 country-level observations. $^{8}$

As discussed in the previous sub-section, we perform our analysis at three different aggregation levels: (1) total economy, (2) total manufacturing and (3) manufacturing of machinery and equipment that includes manufacturing of renewable energy technologies. Accordingly, three sets of data are collected. Table 2 provides the detailed description and measurement units of each variable used in the analysis.

In Model 1, gross domestic product (GDP) is used as a proxy for total economic output. Gross fixed capital formation proxies the economy's capital input, total employment proxies labor input, and final energy consumption is used for energy input. In Model 2, gross value added in the manufacturing sector, gross fixed capital formation in manufacturing sector, total employment in manufacturing sector and final energy consumption of the manufacturing sector proxy total manufacturing's output, capital, labor and energy, respectively. Finally, Model 3 adjusts the variables of Model 2 for the sector of manufacturing of machinery and equipment. This sector corresponds to class 28 in NACE Rev. 2. According to NACE Rev. 2, the statistical classification of economic activities in the European Community (European Commission (2008), class 28 includes the manufacture of wind turbines and solar collectors used for heating of water. ${ }^{9}$ All models use total solar photovoltaic and thermal electric capacity and total wind electrical capacity that reflects the EU's renewable energy policy efforts to speed up the learning-by-doing process in the manufacturing sectors.

From the descriptive statistics in Table 3 it is evident that, on average, the manufacturing sector in the EU is rather energy intensive as it uses about 29 per cent of the total economy's final energy consumption. The average share of total employment in this sector is about 18 per cent. The gross value added and final energy consumption of manufacturing of machinery and equipment correspond, on average, to about 12 per cent and 7 per cent of total manufacturing's gross value added and final energy consumption, respectively.

8. In September 2015, the data for the year 2013 was not available for total manufacturing and manufacturing of machinery and equipment, thus the data for the period 1990-2013 is only available at the 'total economy' level.

9. It is important to note that class 28 in NACE Rev. 2 does not include manufacture of solar cells used for direct transformation of solar power to electricity. This activity should be classified in NACE Rev. 2 as Class 26.11 manufacture of electronic components. However, this is not explicitly stated in NACE Rev. 2 (European Commission, 2008). For exploratory purposes we performed the same analysis for manufacture of electronic components. However, we did not find any significant results related to wind and solar capacity variables. The full results of this exercise are available from the authors upon request. 
Table 2: Description of the Variables

\begin{tabular}{|c|c|c|}
\hline Variable & Description & Measurement units \\
\hline \multicolumn{3}{|l|}{ Total Economy } \\
\hline $\begin{array}{l}\text { Gross domestic } \\
\text { product }\end{array}$ & $\begin{array}{l}\text { Gross domestic product at market prices, chain-linked volumes, } \\
\text { reference year } 2000 \text { (at } 2000 \text { exchange rates) }\end{array}$ & Million euro \\
\hline $\begin{array}{l}\text { Gross fixed capital } \\
\text { formation }\end{array}$ & $\begin{array}{l}\text { Gross fixed capital formation, chain-linked volumes, reference year } \\
2000 \text { (at } 2000 \text { exchange rates) }\end{array}$ & Million euro \\
\hline Total employment & Total employment in the economy (Labor Force Survey) & 1000 people \\
\hline $\begin{array}{l}\text { Final energy } \\
\text { consumption }\end{array}$ & $\begin{array}{l}\text { All energy supplied to industry, transport, households, services and } \\
\text { agriculture; excludes deliveries to the energy transformation } \\
\text { sector and the energy industries themselves }\end{array}$ & Terajoules \\
\hline \multicolumn{3}{|c|}{ Total Manufacturing, C NACE Rev.2 } \\
\hline Gross value added & $\begin{array}{l}\text { Gross value added (at basic prices) in manufacturing, chain-linked } \\
\text { volumes, reference year } 2000 \text { (at } 2000 \text { exchange rates) }\end{array}$ & Million euro \\
\hline $\begin{array}{l}\text { Gross fixed capital } \\
\text { formation }\end{array}$ & $\begin{array}{l}\text { Gross fixed capital formation in manufacturing, chain-linked } \\
\text { volumes, reference year } 2005 \text { (at } 2005 \text { exchange rates) }\end{array}$ & Million euro \\
\hline Total employment & Total employment in manufacturing & 1000 people \\
\hline $\begin{array}{l}\text { Final energy } \\
\text { consumption }\end{array}$ & $\begin{array}{l}\text { All energy supplied to manufacturing industry; excludes deliveries } \\
\text { to the energy transformation sector and the energy industries } \\
\text { themselves }\end{array}$ & $\begin{array}{l}\text { Thousand tons of oil } \\
\text { equivalent (TOE) }\end{array}$ \\
\hline \multicolumn{3}{|c|}{ Manufacture of machinery and equipment, 28 NACE Rev. 2} \\
\hline Gross value added & $\begin{array}{l}\text { Gross value added (at basic prices) in manufacture of machinery } \\
\text { and equipment, chain-linked volumes, reference year } 2005 \text { (at } \\
2005 \text { exchange rates) }\end{array}$ & Million euro \\
\hline $\begin{array}{l}\text { Gross fixed capital } \\
\text { formation }\end{array}$ & $\begin{array}{l}\text { Gross fixed capital formation in manufacture of machinery and } \\
\text { equipment, chain-linked volumes, reference year } 2005 \text { (at } 2005 \\
\text { exchange rates) }\end{array}$ & Million euro \\
\hline Total employment & Total employment in manufacture of machinery and equipment & 1000 people \\
\hline $\begin{array}{l}\text { Final energy } \\
\text { consumption }\end{array}$ & $\begin{array}{l}\text { All energy supplied to machinery industry; excludes deliveries to } \\
\text { the energy transformation sector and the energy industries } \\
\text { themselves }\end{array}$ & $\begin{array}{l}\text { Thousand tons of oil } \\
\text { equivalent (TOE) }\end{array}$ \\
\hline \multicolumn{3}{|l|}{ RES capacity variables } \\
\hline $\begin{array}{l}\text { Wind electrical } \\
\text { capacity }\end{array}$ & $\begin{array}{l}\text { Wind electrical capacity of main activity producers and } \\
\text { autoproducers }\end{array}$ & Megawatts \\
\hline $\begin{array}{l}\text { Solar photovoltaic and } \\
\text { thermal electric } \\
\text { capacity }\end{array}$ & Solar photovoltaic and solar thermal electric net maximum capacity & Megawatts \\
\hline
\end{tabular}

\section{RESULTS AND DISCUSSION}

The empirical analysis is performed by estimating a fixed-effect model and the three variants of heterogeneous panel models motivated by different assumptions as indicated in the empirical approach section. Before presenting the results from the various estimators, it is important to present the time series properties of the data series as well as information on cross-sectional dependence. We tested each of the series for unit root for each aggregation level (total economy, manufacturing and machinery) using Pesaran's (2007) unit root test. ${ }^{10}$ The results for the unit root test are presented in Table A1 in the appendix and provide evidence in support of an I(1) process for each of the

10. This unit root test allows for both heterogeneity and cross-sectional dependency in the unit root testing. 
Table 3: Descriptive Statistics, EU-15

\begin{tabular}{|c|c|c|c|c|c|c|}
\hline Variable & Measurement units & No. of obs. & Mean & Std. dev. & Min & Max \\
\hline \multicolumn{7}{|l|}{ Total Economy } \\
\hline Gross domestic product & Million euro & 339 & 612462.6 & 649556.5 & 16337.6 & 2353982 \\
\hline Gross fixed capital formation & Million euro & 334 & 120188.3 & 122965.5 & 3198.1 & 455126.1 \\
\hline Total employment & 1000 people & 327 & 10875.4 & 11220.6 & 162.7 & 40079.9 \\
\hline Final energy consumption & Terajoules & 360 & 2550878 & 2670570 & 4491.8 & 9674839 \\
\hline \multicolumn{7}{|c|}{ Total Manufacturing, C NACE Rev. 2} \\
\hline Gross value added & Million euros & 308 & 100199.5 & 114871.4 & 1461.3 & 509833.8 \\
\hline Gross fixed capital formation & Million euros & 289 & 16216.3 & 18557.3 & 322.9 & 67215.4 \\
\hline Total employment & 1000 people & 287 & 1922.4 & 2233.3 & 31.7 & 10088 \\
\hline Final energy consumption & Thousands TOE & 345 & 17465.1 & 16523 & 600.6 & 72167.1 \\
\hline \multicolumn{7}{|c|}{ Manufacture of machinery and equipment, 28 NACE Rev. 2} \\
\hline Gross value added & Million euros & 261 & 11486.6 & 17271.3 & 249.6 & 76425.7 \\
\hline Gross fixed capital formation & Million euros & 251 & 1340.3 & 1914.3 & 22.2 & 8939.3 \\
\hline Total employment & 1000 people & 245 & 205.4 & 289.2 & 12.6 & 1436 \\
\hline Final energy consumption & Thousands TOE & 335 & 1199.9 & 1496.5 & 8.3 & 5984.1 \\
\hline \multicolumn{7}{|l|}{ RES proxy variables } \\
\hline Wind electrical capacity* & Megawatts & 360 & 2238.8 & 5188.6 & 1 & 34660 \\
\hline $\begin{array}{l}\text { Solar photovoltaic and thermal } \\
\text { electric capacity* }\end{array}$ & Megawatts & 360 & 732.0 & 3482.3 & 1 & 36337 \\
\hline
\end{tabular}

* Note that as several sample countries for a few years had no wind or solar power capacity, in order to be able to transform the data series to logarithms we have added one to the whole set of data on renewables.

series at the 5 per cent statistical significance level, except for energy consumption at the total economy aggregation level, where it is $I(0){ }^{11}$

Moreover, we tested for cross-sectional dependence. ${ }^{12}$ The results presented in Table 4 indicate that each of the series in our data could not pass the null hypothesis test of cross-sectional independence, implying that each of the data series are correlated across panel units and therefore the econometric strategy should incorporate this into the estimation process to reduce the potential problem of producing biased estimates.

We also tested for cointegration, since in general, all series in our data-set follow a $I(1)$ process and therefore we need to test whether there is a long-run relationship between the variables as specified in Eq. (3). Pedroni's (1999) panel cointegration approach was implemented in the testing procedure, and based on the $t$ (non-parametric $t$-test) and Augmented Dickey Fuller (ADF) test statistics, the null hypothesis of no cointegration relationship is rejected at the 5 per cent significance

11. A process is said to be stationary if its mean and variance are time invariant. Such a time series will tend to return to its mean (mean reversion) and will have fluctuations around the mean that are constant. Time series variables that exhibit such a process are said to be stationary and are referred to as integration of order zero, $I(0)$. For illustration, suppose the variable $y_{t}$ is expressed as $y_{t}=a y_{t-1}+e_{t}$ (a first order autoregressive process), where $e_{t}$ is a white noise (random error term in general). Using the backshift operator $(B), y_{t}-a B y_{t}=e_{t}$ or $y_{t}(1-a B)=e_{t}$. If $a<1, y_{t}$ will always return to its mean and refer to as a stationary series, thus $I(0)$. On the other hand, if $a>1, y_{t}$ will not reverse to its mean, a non-stationary series denoted as an $I(d)$, where $d$ is the order of integration greater than zero. If $y_{t}$ is non-stationary but a change in $y_{t}$ is stationary, then $y_{t}$ is said to be $I(1)$, meaning that the change in $y_{t}$ has a constant mean or variance or both.

12. A CD test, which employs correlation coefficient between the time series for each of the panel units and uses it to calculate the test statistic.

Copyright (C) 2017 by the IAEE. All rights reserved. 
Table 4: Cross-section Dependence Test (CD) for

Each Series for Each Aggregation Level

(total economy, manufacturing and machinery)

\begin{tabular}{|c|c|c|c|}
\hline Variable & CD test & $p$-value & Average correlation \\
\hline \multicolumn{4}{|c|}{ Total Economy } \\
\hline $\ln \mathrm{Y}$ & 41.25 & 0.000 & 0.908 \\
\hline $\ln K$ & 30.7 & 0.000 & 0.671 \\
\hline $\ln L$ & 31.62 & 0.000 & 0.688 \\
\hline $\operatorname{lnEC}$ & 44.48 & 0.000 & 0.989 \\
\hline $\operatorname{lnSOL}$ & 42.32 & 0.000 & 0.906 \\
\hline $\operatorname{lnWND}$ & 42.74 & 0.000 & 0.950 \\
\hline \multicolumn{4}{|c|}{ Manufacturing } \\
\hline $\ln Y$ & 20.95 & 0.000 & 0.497 \\
\hline $\ln K$ & 15.4 & 0.000 & 0.372 \\
\hline $\operatorname{lnL}$ & 26.67 & 0.000 & 0.656 \\
\hline $\operatorname{lnEC}$ & 15.08 & 0.000 & 0.385 \\
\hline $\operatorname{lnSOL}$ & 19.68 & 0.000 & 0.896 \\
\hline $\operatorname{lnWND}$ & 38.67 & 0.000 & 0.945 \\
\hline \multicolumn{4}{|c|}{ Machinery } \\
\hline $\ln Y$ & 20.96 & 0.000 & 0.640 \\
\hline $\ln K$ & 6.79 & 0.000 & 0.196 \\
\hline $\ln L$ & 3.63 & 0.000 & 0.114 \\
\hline $\operatorname{lnEC}$ & 1.52 & 0.129 & 0.056 \\
\hline $\operatorname{lnSOL}$ & 29.03 & 0.000 & 0.901 \\
\hline $\operatorname{lnWND}$ & 30.57 & 0.000 & 0.949 \\
\hline
\end{tabular}

Notes: Under the null hypothesis of cross-section independence $\mathrm{CD} \sim \mathrm{N}$ $(0,1)$, we reject the null of cross-section independence at the $5 \%$ significance level, implying cross-sectional dependence.

level, implying evidence of a long-run relationship between the variables. In the econometric literature, rejection of the null of no cointergration for linear combination of $I(1)$ variables implies that the variables in the model are related in equilibrium, which in general is a long-term phenomenon, hence the reference to such as a long-run relationship. These test statistics are reported in the appendix, Table A2.

The results for each of the four estimators (fixed effect, MG, CCMG and AMG) for the long-run model are presented in Table 5. In discriminating between the estimators, we relied on the models' diagnostics, especially if the models' residuals pass the cross-sectional independence test and are stationary- $I(0)$. The diagnostic test results as reported in Table 5 favor only the AMG estimator-its residuals are stationary, implying non-spurious regression, and also pass the CD test at the 5 per cent significance level, which means that estimates are free from unobserved common factors bias. Although the residuals from both the MG and the CCMG estimators are also stationary, they did not pass the CD test at the 5 per cent significance level for all three data aggregation levels. The FE model's residuals only passed the CD test for the economy and manufacturing levels of data aggregation at the 5 per cent level of significance. Its residuals are however $I(1)$ for all three levels of our data analysis. The diagnostic tests therefore provide support for the AMG estimator relative to the other three estimators.

Table 5 presents the long-run elasticities from all estimated models. According to the estimates from the AMG model, in the long run, a one per cent increase in solar and wind power 
Table 5: Regression Results for Four Different Estimators for Long-run Models

\begin{tabular}{|c|c|c|c|c|}
\hline Variables & (FE) & (MG) & (AMG) & (CCMG) \\
\hline \multicolumn{5}{|c|}{ Total Economy } \\
\hline \multirow{2}{*}{$\ln \mathrm{K}$} & $0.190 * *$ & $0.311 * * *$ & $0.176^{* * *}$ & $0.179 * * *$ \\
\hline & $(0.081)$ & $(0.035)$ & $(0.022)$ & $(0.018)$ \\
\hline \multirow[t]{2}{*}{$\ln L$} & $0.501 * *$ & 0.0511 & $0.194 * *$ & 0.178 \\
\hline & $(0.220)$ & $(0.132)$ & $(0.079)$ & $(0.130)$ \\
\hline \multirow[t]{2}{*}{$\operatorname{lnEC}$} & 0.004 & $0.004 * * *$ & $0.002 * *$ & $0.088 * *$ \\
\hline & $(0.003)$ & $(0.001)$ & $(0.001)$ & $(0.042)$ \\
\hline \multirow[t]{2}{*}{$\operatorname{lnSOL}$} & $-0.017 * *$ & $-0.010 *$ & $-0.005^{*}$ & -0.002 \\
\hline & (0.007) & $(0.005)$ & $(0.003)$ & $(0.003)$ \\
\hline \multirow[t]{2}{*}{$\operatorname{lnWND}$} & 0.001 & 0.006 & $-0.007 * *$ & -0.001 \\
\hline & $(0.007)$ & $(0.005)$ & $(0.003)$ & $(0.008)$ \\
\hline \multicolumn{5}{|l|}{ Diagnostics } \\
\hline \multirow[t]{2}{*}{ CD test } & -0.76 & 10.20 & -1.21 & 7.32 \\
\hline & $(0.448)$ & $(0.000)$ & $(0.226)$ & $(0.000)$ \\
\hline Integration & $I(1)$ & $I(0)$ & $I(0)$ & $I(0)$ \\
\hline \multirow[t]{2}{*}{ No. of observations } & 307 & 307 & 307 & 307 \\
\hline & & facturing & & \\
\hline \multirow[t]{2}{*}{$\ln K$} & 0.134 & $0.142 * * *$ & $0.0922 * * *$ & $0.175^{* * *}$ \\
\hline & $(0.088)$ & $(0.032)$ & $(0.024)$ & $(0.053)$ \\
\hline \multirow[t]{2}{*}{$\ln L$} & 0.332 & 0.196 & $0.234 * *$ & 0.275 \\
\hline & $(0.260)$ & $(0.136)$ & $(0.118)$ & $(0.438)$ \\
\hline \multirow[t]{2}{*}{$\operatorname{lnEC}$} & $0.427 * *$ & $0.496 * * *$ & $0.181 * * *$ & $0.288 * *$ \\
\hline & $(0.150)$ & $(0.132)$ & $(0.053)$ & $(0.131)$ \\
\hline \multirow[t]{2}{*}{$\operatorname{lnSOL}$} & $-0.034 * *$ & -0.005 & 0.003 & $-0.015^{*}$ \\
\hline & $(0.014)$ & $(0.006)$ & $(0.004)$ & $(0.008)$ \\
\hline \multirow[t]{2}{*}{$\operatorname{lnWND}$} & -0.008 & -0.010 & -0.013 & $-0.044 * *$ \\
\hline & $(0.019)$ & $(0.020)$ & $(0.011)$ & $(0.021)$ \\
\hline \multicolumn{5}{|l|}{ Diagnostics } \\
\hline \multirow[t]{2}{*}{ CD test } & 0.19 & 7.63 & -0.42 & 2.59 \\
\hline & $(0.846)$ & $(0.000)$ & $(0.677)$ & $(0.010)$ \\
\hline Integration & $I(1)$ & $I(0)$ & $I(0)$ & $I(0)$ \\
\hline \multirow[t]{2}{*}{ No. of observations } & 275 & 275 & 275 & 275 \\
\hline & & hinery & & \\
\hline \multirow[t]{2}{*}{$\ln K$} & $0.111^{*}$ & $0.151 * * *$ & $0.127 * * *$ & $0.252 * * *$ \\
\hline & $(0.060)$ & $(0.039)$ & $(0.034)$ & $(0.072)$ \\
\hline \multirow[t]{2}{*}{$\ln L$} & $0.531 * * *$ & $0.715 * * *$ & $0.481 * *$ & $0.730 * * *$ \\
\hline & $(0.161)$ & $(0.215)$ & $(0.192)$ & $(0.231)$ \\
\hline \multirow[t]{2}{*}{$\operatorname{lnEC}$} & -0.049 & 0.002 & 0.037 & 0.091 \\
\hline & $(0.038)$ & $(0.074)$ & $(0.054)$ & $(0.127)$ \\
\hline \multirow[t]{2}{*}{$\operatorname{lnSOL}$} & $-0.044 * * *$ & 0.016 & 0.012 & $-0.036 * *$ \\
\hline & $(0.012)$ & $(0.031)$ & $(0.011)$ & $(0.015)$ \\
\hline \multirow[t]{2}{*}{$\operatorname{lnWND}$} & $0.023 *$ & $-0.062 * * *$ & -0.017 & $-0.058 * *$ \\
\hline & $(0.012)$ & $(0.022)$ & $(0.022)$ & $(0.027)$ \\
\hline Diagnostics & & & & \\
\hline CD Test & & & & \\
\hline Integration & 8.06 & 10.89 & -0.81 & 2.25 \\
\hline & $(0.000)$ & $(0.000)$ & $(0.417)$ & $(0.024)$ \\
\hline$I(0 / 1)$ & $I(0)$ & $I(0)$ & $I(0)$ & \\
\hline No. of observations & 220 & 220 & 220 & 220 \\
\hline
\end{tabular}

Notes: Under the null hypothesis of cross-section independence $\mathrm{CD} \sim \mathrm{N}(0,1)$, integration indicates if the residual is stationary $I(0)$, non-stationary $I(1)$ or mixed $I(0 / 1)$. Where mixed imply both $I(0)$ and $I(1)$, depending on the lag length of 0 and 2 for the unit root test. Fixed effect, mean group, augmented mean group and the common corrected mean group models are represented as FE, MG, AMG and CCMG, respectively. Standard errors are in parentheses (robust standard errors), * $p<0.05$, ** $p<0.01, * * * p<0.001$. Capital elasticity estimates are known to be notoriously difficult to estimate precisely, especially at aggregate macro level as noted in Eberhardt, Helmers and Strauss (2013). Our estimates are close in magnitude to those (significant estimates) in Eberhardt, Helmers and Strauss (2013). 
capacity will result in a 0.005 and a 0.007 per cent drop in total EU GDP, respectively. Our results oppose common findings of comparable empirical studies (summarized in Table 1) that expansion of renewable energy enhances economic growth in the long run. Interestingly, all our estimated long-run models provide negative long-run estimates for wind and solar capacity, except in the case of the fixed-effect and mean group models (models that do not account for unobserved common factors), where the wind capacity estimate is positive but insignificant at any conventional significance level.

One might expect the positive effects of renewable energy capacity to be visible at least in manufacturing sectors. However, our estimators for our variables of interest remain insignificant for total manufacturing and the sector of machinery and equipment (see the AMG model in Table 5). We therefore conclude that, to date, we find no evidence to support Hypothesis 1, i.e. that the increases in wind and solar power capacity induced by the EU's renewable energy support policy lead to economic growth in the long run. In fact, our results tend to support the opposite relationship: increases in wind and solar power capacity are associated with negative economic growth in the EU-15 member states, at least at the total economy level.

Table 6 reports the panel causality results from estimating the panel vector error correction models for each data aggregation level. In line with Ohler and Fetters (2014), we find evidence of short-term positive Granger causality from wind capacity to output at the total economy and manufacturing data aggregation levels. This result lends support to our Hypothesis 2, suggesting that in the short run, the wind capacity expansion induced by the EU's renewable policy has a direct positive impact on the EU economy. This finding could be explained by the fact that local EU wind turbine manufacturers have been competitive across the globe (European Commission, 2014).

When it comes to the effects of wind capacity expansion on employment, we find that wind capacity has a positive and statistically significant impact on total employment in the short run at the total economy level (similar to the findings of Ohler and Fetters, 2014), but not at the manufacturing and machinery sector levels. While our finding lends support to Hypothesis 2 for the case of wind capacity development, we do not find similar results for the case of solar capacity.

The results presented in Table 6 show that solar capacity expansion has a negative effect on output not only in the long run but also in the short run (though this latter result is only significant at the machinery level). Given the very high subsidies per installed capacity for solar power, this finding might be explained by crowding-out of capital from more productive to less productive sectors. However, we find that solar power capacity expansion has a positive impact on employment in manufacturing of machinery and equipment (the machinery level), whereas this is not the case at the total manufacturing and total economy levels.

In summary, our findings on the impacts of renewable energy expansion on total economic growth and total employment give us some evidence to support Hypothesis 2 in the case of wind power capacity expansion but not in the case of solar. The effects of increases in solar energy capacity to date are only evident in the sector of manufacturing of machinery and equipment.

Overall, the results of our analysis support the common reasoning that the effect of increasing capacity into renewable energy generation on economic activity and employment in economies and RES-related industries is positive in the short run. However, in the long run, the positive short-run effects are offset by negative impacts. Our research does not allow us to identify what these negative factors are, but we argue that crowding out of productive investments by green energy investments could be the most likely explanation. Further investigation of this is left for future research.

As a final step, we performed the robustness tests - an identical analysis but replaced the solar and wind power capacity variable with solar and wind power production. The main reason 
Table 6: Causality Test in Panel ECM Model with Heterogeneous Parameters

\begin{tabular}{|c|c|c|c|c|c|c|c|}
\hline \multicolumn{8}{|c|}{ Sources of causation (independent variables) } \\
\hline Dep. variable & $\Delta \ln Y$ & $\Delta \ln K$ & $\Delta \operatorname{lnL}$ & $\Delta \ln E C$ & $\Delta \operatorname{lnSOL}$ & $\Delta \operatorname{lnWND}$ & ECT \\
\hline \multicolumn{8}{|c|}{ Total Economy } \\
\hline$\Delta \ln Y$ & & $\begin{array}{c}88.60 * * * \\
{[0.26]}\end{array}$ & $\begin{array}{c}25.21 * \\
{[-0.13]}\end{array}$ & $\begin{array}{c}56.06 * * * \\
{[-0.05]}\end{array}$ & $\begin{array}{l}13.87 \\
{[0.00]}\end{array}$ & $\begin{array}{c}41.34 * * * \\
{[0.02]}\end{array}$ & $\begin{array}{c}56.61 * * * \\
{[-0.39]}\end{array}$ \\
\hline$\Delta \ln K$ & $\begin{array}{c}92.51 * * * \\
{[0.85]}\end{array}$ & & $\begin{array}{c}125.1 * * * \\
{[1.43]}\end{array}$ & $\begin{array}{l}12.36 \\
{[0.32]}\end{array}$ & $\begin{array}{c}17.92 \\
{[-0.01]}\end{array}$ & $\begin{array}{c}27.01 * \\
{[0.08]}\end{array}$ & $\begin{array}{c}71.36 * * * \\
{[-0.27]}\end{array}$ \\
\hline$\Delta \operatorname{lnL}$ & $\begin{array}{l}36.39 * * \\
{[-0.02]}\end{array}$ & $\begin{array}{c}36.01 * * \\
{[0.04]}\end{array}$ & & $\begin{array}{c}54.87 * * * \\
{[-0.07]}\end{array}$ & $\begin{array}{c}11.02 \\
{[0.00]}\end{array}$ & $\begin{array}{c}132.0 * * * \\
{[0.01]}\end{array}$ & $\begin{array}{c}327.4 * * * \\
{[-0.45]}\end{array}$ \\
\hline$\Delta \ln E C$ & $\begin{array}{c}28.09 * \\
{[3.2]}\end{array}$ & $\begin{array}{c}43.95^{* *} \\
{[3.07]}\end{array}$ & $\begin{array}{c}55.22 * * * \\
{[-0.02]}\end{array}$ & & $\begin{array}{c}132.2^{* * * *} \\
{[0.31]}\end{array}$ & $\begin{array}{l}36.67 * * \\
{[-0.50]}\end{array}$ & $\begin{array}{c}53.17 * * * \\
{[-1.91]}\end{array}$ \\
\hline$\Delta \operatorname{lnSOL}$ & $\begin{array}{l}33.70^{* *} \\
{[-1.59]}\end{array}$ & $\begin{array}{c}66.80 * * * \\
{[2.46]}\end{array}$ & $\begin{array}{c}16.76 \\
{[-1.14]}\end{array}$ & $\begin{array}{c}48.85 * * * \\
{[2.76]}\end{array}$ & & $\begin{array}{c}50.37 * * * \\
{[-0.58]}\end{array}$ & $\begin{array}{c}145.9 * * * \\
{[-0.30]}\end{array}$ \\
\hline$\Delta \ln W N D$ & $\begin{array}{l}33.68 * * \\
{[-4.01]}\end{array}$ & $\begin{array}{c}63.34 * * * \\
{[-0.07]}\end{array}$ & $\begin{array}{c}28.55^{*} \\
{[1.36]}\end{array}$ & $\begin{array}{c}71.96 * * * \\
{[1.37]}\end{array}$ & $\begin{array}{c}23.47 * \\
{[-0.18]}\end{array}$ & & $\begin{array}{c}114.3 * * * \\
{[-0.41]}\end{array}$ \\
\hline \multicolumn{8}{|c|}{ Manufacturing } \\
\hline$\Delta \ln Y$ & & $\begin{array}{c}68.68^{* *} \\
{[0.13]}\end{array}$ & $\begin{array}{l}30.75^{* *} \\
{[-0.21]}\end{array}$ & $\begin{array}{c}59.94 * * * \\
{[0.21]}\end{array}$ & $\begin{array}{c}20.58 \\
{[-0.02]}\end{array}$ & $\begin{array}{c}55.40 * * * \\
{[0.02]}\end{array}$ & $\begin{array}{c}92.94 * * * \\
{[-0.61]}\end{array}$ \\
\hline$\Delta \ln \mathrm{K}$ & $\begin{array}{c}14.74 \\
{[-0.13]}\end{array}$ & & $\begin{array}{c}78.82 * * * \\
{[1.84]}\end{array}$ & $\begin{array}{c}14.52 \\
{[-0.13]}\end{array}$ & $\begin{array}{c}39.39 * * * \\
{[0.03]}\end{array}$ & $\begin{array}{c}15.75 \\
{[0.11]}\end{array}$ & $\begin{array}{c}130.95^{* * *} * \\
{[-0.85]}\end{array}$ \\
\hline$\Delta \operatorname{lnL}$ & $\begin{array}{c}24.15^{*} \\
{[-0.01]}\end{array}$ & $\begin{array}{l}23.85^{*} \\
{[0.01]}\end{array}$ & & $\begin{array}{l}24.04 * \\
{[0.03]}\end{array}$ & $\begin{array}{c}17.43 \\
{[-0.01]}\end{array}$ & $\begin{array}{l}13.43 \\
{[0.01]}\end{array}$ & $\begin{array}{c}167.94 * * * \\
{[-0.26]}\end{array}$ \\
\hline$\Delta \operatorname{lnEC}$ & $\begin{array}{c}19.39 \\
{[-0.13]}\end{array}$ & $\begin{array}{c}131.48 * * * \\
{[-0.06]}\end{array}$ & $\begin{array}{c}18.26 \\
{[-2.43]}\end{array}$ & & $\begin{array}{c}18.46 \\
{[-0.16]}\end{array}$ & $\begin{array}{c}36.34 * * * \\
{[0.19]}\end{array}$ & $\begin{array}{c}99.48 * * * \\
{[-1.45]}\end{array}$ \\
\hline $\operatorname{lnSOL}$ & $\begin{array}{c}21.93 \\
{[-0.65]}\end{array}$ & $\begin{array}{c}23.83^{*} \\
{[0.09]}\end{array}$ & $\begin{array}{c}21.90 \\
{[-9.39]}\end{array}$ & $\begin{array}{l}21.35 \\
{[2.34]}\end{array}$ & & $\begin{array}{l}31.58 * * \\
{[-0.18]}\end{array}$ & $\begin{array}{c}22.63^{*} \\
{[-0.28]}\end{array}$ \\
\hline$\Delta \ln W N D$ & $\begin{array}{c}23.95 * \\
{[-1.45]} \\
\end{array}$ & $\begin{array}{c}18.64 \\
{[-0.10]}\end{array}$ & $\begin{array}{c}27.79 * \\
{[-5.21]}\end{array}$ & $\begin{array}{c}15.89 \\
{[1.84]}\end{array}$ & $\begin{array}{c}17.05 \\
{[-0.23]}\end{array}$ & & $\begin{array}{c}46.84 * * * \\
{[-0.46]} \\
\end{array}$ \\
\hline \multicolumn{8}{|c|}{ Machinery } \\
\hline$\Delta \ln \mathrm{Y}$ & & $\begin{array}{c}26.75 * * * \\
{[0.17]}\end{array}$ & $\begin{array}{c}43.57 * * * \\
{[0.52]}\end{array}$ & $\begin{array}{c}40.69 * * * \\
{[-0.23]}\end{array}$ & $\begin{array}{c}42.07 * * * \\
{[-0.05]}\end{array}$ & $\begin{array}{c}8.32 \\
{[0.08]}\end{array}$ & $\begin{array}{c}136.28 * * * \\
{[-0.59]}\end{array}$ \\
\hline$\Delta \ln K$ & $\begin{array}{l}10.75 \\
{[0.83]}\end{array}$ & & $\begin{array}{c}20.18 * \\
{[-0.45]}\end{array}$ & $\begin{array}{c}11.31 \\
{[-0.16]}\end{array}$ & $\begin{array}{c}9.31 \\
{[0.19]}\end{array}$ & $\begin{array}{c}13.22 \\
{[-0.59]}\end{array}$ & $\begin{array}{c}63.08 * * * \\
{[-0.69]}\end{array}$ \\
\hline$\Delta \operatorname{lnL}$ & $\begin{array}{l}18.37 * \\
{[0.47]}\end{array}$ & $\begin{array}{c}8.85 \\
{[-0.16]}\end{array}$ & & $\begin{array}{l}17.06 \\
{[0.08]}\end{array}$ & $\begin{array}{c}28.21 * * \\
{[0.06]}\end{array}$ & $\begin{array}{c}4.94 \\
{[-0.14]}\end{array}$ & $\begin{array}{c}67.42 * * * \\
{[-0.15]}\end{array}$ \\
\hline$\Delta \ln E C$ & $\begin{array}{l}25.66^{* *} \\
{[-1.04]}\end{array}$ & $\begin{array}{c}16.59 \\
{[-0.08]}\end{array}$ & $\begin{array}{l}23.35^{* *} \\
{[-0.90]}\end{array}$ & & $\begin{array}{c}17.48 \\
{[-0.23]}\end{array}$ & $\begin{array}{c}6.81 \\
{[0.48]}\end{array}$ & $\begin{array}{c}50.55^{* * * *} \\
{[-1.04]}\end{array}$ \\
\hline$\Delta \operatorname{lnSOL}$ & $\begin{array}{c}14.17 \\
{[-7.26]}\end{array}$ & $\begin{array}{c}7.24 \\
{[3.29]}\end{array}$ & $\begin{array}{l}11.17 \\
{[6.58]}\end{array}$ & $\begin{array}{c}15.77 \\
{[-0.58]}\end{array}$ & & $\begin{array}{l}22.24 * \\
{[1.79]}\end{array}$ & $\begin{array}{c}44.10^{* * *} * \\
{[-0.17]}\end{array}$ \\
\hline$\Delta \operatorname{lnWND}$ & $\begin{array}{c}9.78 \\
{[1.80]}\end{array}$ & $\begin{array}{c}7.73 \\
{[-0.38]}\end{array}$ & $\begin{array}{c}4.38 \\
{[-1.76]}\end{array}$ & $\begin{array}{l}13.58 \\
{[0.86]}\end{array}$ & $\begin{array}{c}9.68 \\
{[0.37]}\end{array}$ & & $\begin{array}{c}35.01 * * * * \\
{[0.55]}\end{array}$ \\
\hline
\end{tabular}

The test statistics are the values NOT in square brackets and the estimated coefficients are presented in square brackets. The null hypothesis is Granger non-causality. Level of significance is represented by asterisks: * $p<0.05, * * p<0.01$, $* * * p<0.001$. Number of observations at GDP, manufacturing and machinery level are 292, 260 and 207, respectively.

for doing this was that we wanted to see whether using a common approach and having a renewable electricity production variable instead of our suggested capacity variable changes our results. Indeed, it turns out that this exercise does change both the short-run and the long-run effects compared with our main findings, and the results are generally in line with similar studies described in Section $2 .{ }^{13}$ One should note that we do not consider the previous efforts to link renewable energy con-

13. The full results of this exercise are available from the authors upon request. 
sumption/production with economic growth using time series data and models as "wrong" or as "not good enough like ours". This robustness check shows that using an alternative for the production data (installed capacity) may profoundly affect final results. This highlights the importance of considering both measures of renewable energy expansion. As discussed above, the approach of using installed capacity instead of production has its own advantages and limitations. The reason why we focus on installed capacity in our study is that installed capacity data better reflects policies promoting wind and solar energy technologies.

We also estimated our model using a dynamic OLS (DOLS), in line with Ohler and Fetters (2014) for their long-run model — a paper most closely related to our study — to check if the negative sign is due to our methodology not completely correcting for possible endogeneity issues for the long-run model, especially the potential feedback effect between GDP and electricity consumption. The DOLS adds both leads and lags of changes in each covariate to the model as a way of controlling for endogeneity. The addition of leads and lags of changes in each covariate reduces significantly our sample size and as a consequence we only considered the total economy level, since it is only at this level that we have a relatively good degree of freedom after running the DOLS with a lead and lag structure of 1 . The results in terms of the sign (not significance) on both wind and solar capacity are generally consistent with the main results from the augmented mean group (AMG) estimator (see Table A3 in the appendix).

Naturally, there are some potential limitations of our study. First, one might note the limitation of the approach of using renewable installed capacity data instead of renewable energy consumption/generation data to capture output gains due to technological advancements, in particular, for the case of wind power. A significant progress has been made in the design of wind turbines to increase their capacity factors. For example, today, tailored solutions are available for distinct site specific conditions-specific turbines, combining larger blades with comparatively small power generators, are used for sites with less perfect wind conditions to increase the full load hours and, consequently, the power output. Over the studied time period, this may lead to higher capacity utilization factors, making installed capacity not a perfect proxy to capture all of the scale effects and technological advancements. However, we think that capacity data is still better suited for the specific purpose of our study. The presence of data noise in renewable energy consumption/production data because of weather and other factors (maintenance) makes it difficult to capture slow changing output gains due to learning-by-doing and other knowledge spillover effects in the wind and solar power related industries.

Second, it should be noted that our results apply only for the countries in our sample. In this respect, our study is different from most of the studies summarized in our literature review. The EU policies encouraging renewable technologies and energy in Europe could also lead to technological advancement spillovers and other positive effects in other countries, which we do not capture in our analysis.

\section{CONCLUSIONS AND FINAL REMARKS}

Energy from renewable energy sources has attracted a lot of interest both in academia and among policy makers in the last decade, especially in the EU region. This surge in interest in renewable energy and consequently policies targeting the promotion of renewable energy is a result of the increased awareness of the impact of human activities on the climate and the security concerns posed by high reliance on fossil fuel-based energy sources. Promoting renewable energy is therefore seen as one option to mitigate climate change and foster learning-by-doing and knowledge spillovers in related manufacturing sectors. It is also seen as a measure to reduce energy insecurity and as a 
growth-enhancing measure via job creation. These potential positive outcomes associated with renewable energy make it very appealing to policy makers.

In this paper we analyses in detail the impact of the capacity increases in solar and wind power production induced by EU renewable energy policy on output and employment in the EU15 region. Given the EU's Renewable Energy Directive requirement to obtain at least 20 per cent of the EU's total energy needs from renewable sources by 2020, it is important to understand the potential implication of such policy-induced capacity changes on output and employment in both the short run and the long run. As a consequence, we explored several econometric methods that account for unobserved common factor effects, endogeneity and both homogeneous and heterogeneous parameters in order to answer our key questions.

Moreover, instead of relying on renewable energy consumption or generation as commonly done in the literature, we focused on the capacity for solar and wind power generation, which is largely a consequence of the EU's renewable energy policies. In general, our results provide evidence in support of the hypothesis that policy-induced capacity for the generation of wind and solar power promotes growth and/or employment in the short run, yet they do not support the hypothesis that such capacity increases promote growth in the long run. In fact, our findings tend to support the opposite relationship: to date, increases in wind and solar power capacity are associated with negative economic growth in the EU-15 region.

A possible explanation for the negative effect of renewable energy on output in the long run is that the renewable energy technologies are still not developed well enough to benefit from international trade, which could otherwise generate employment opportunities beyond domestic markets to growth-stimulating levels. Another explanation could be that renewable energy investments crowd out investments in more productive EU sectors. However, in general, we must recognize that development of renewable technologies depends not only on policies promoting these technologies but also on the global context that provides opportunities and risks for the renewable sector. They are related to the global demand for renewable energy, interactions between costs of renewable energy and costs of fossil fuel based energy, as well as openness of international markets.

\section{ACKNOWLEDGMENTS}

Paulius Kažukauskas provided excellent research assistance, as well as valuable and detailed comments. We also benefited a lot from comments and suggestions provided by three referees.

\section{REFERENCES}

Apergis, N. and J. E. Payne (2010a). "Renewable energy consumption and economic growth: Evidence from a panel of OECD countries,” Energy Policy 38(1): 656-660. https://doi.org/10.1016/j.enpol.2009.09.002.

Apergis, N. and J. E. Payne (2010b). "Renewable energy consumption and growth in Eurasia," Energy Economics 32(6): 1392-1397. https://doi.org/10.1016/j.eneco.2010.06.001.

Apergis, N. and J. E. Payne (2011). "On the causal dynamics between renewable and non-renewable energy consumption and economic growth in developed and developing countries," Energy Systems 2(3): 299-312. https://doi.org/10.1007/ s12667-011-0037-6.

Apergis, N. and J. E. Payne (2012). "Renewable and non-renewable energy consumption-growth nexus: Evidence from a panel error correction model,” Energy Economics 34: 733-738. https://doi.org/10.1016/j.eneco.2011.04.007.

Apergis, N. and J. E. Payne (2014). "The causal dynamics between renewable energy, real GDP, emissions and oil prices: evidence from OECD countries,” Applied Economics 46(36): 4519-4525. https://doi.org/10.1080/00036846.2014.964834.

Apergis, N., J. E. Payne, K. Menyah, and Y. Wolde-Rufael (2010). "On the causal dynamics between emissions, nuclear energy, renewable energy, and economic growth,” Ecological Economics 69(11): 2255-2260. https://doi.org/10.1016/ j.ecolecon.2010.06.014.

Copyright (C) 2017 by the IAEE. All rights reserved. 
Bayraktutan, Y., M. Yilgör, and S. Ucak (2011). "Renewable Electricity Generation and Economic Growth: Panel-Data Analysis for OECD Members," International Research Journal of Finance and Economics 66: 59-66.

Ben Jebli, M. and S. Ben Youssef (2015). "Output, renewable and non-renewable energy consumption and international trade: Evidence from a panel of 69 countries," Renewable Energy 83: 799-808. https://doi.org/10.1016/ j.renene.2015.04.061.

Canton, J. and ̊̊. Johannesson Lindén (2010). "Support schemes for renewable electricity in the EU," Economic Papers 408 [Online]. Available: http://ec.europa.eu/economy_finance/publications/economic_paper/2010/pdf/ecp408_en.pdf.

Duscha, V., M. Ragwitz, B. Breitschopf, W. Schade, R. Walz, M. Pfaff, E. De Visser, G. Resch, C. Nathani, P. Zagamé, A. Fougeyrollas, and B. Boitier (2014). "Employment and growth effects of sustainable energies in the European Union." Available: https://ec.europa.eu/energy/sites/ener/files/documents/EmployRES-II\%20final\%20report_0.pdf.

Eberhardt, M., C. Helmers, and H. Strauss (2013). "Do spillovers matter when estimating private returns to R\&D?," The Review of Economics and Statistics 95(2): 436-448. https://doi.org/10.1162/REST_a_00272.

Eberhardt, M. and F. Teal (2010). "Productivity analysis in global manufacturing production," Economics Series Working Papers. University of Oxford, Department of Economics.

EirGrid and SONI. (2015). “All-Island Generation Capacity Statement, 2015-2024.” Available: http://www.pleanala.ie/misc/ PCI/PCI1/APPFILE/AppPartOne/Volume\%203B/4.\%20Reference\%20Material/3B_17)\%20EirGrid\%20and\%20SONI\% 20(2015)\%20All\%20Island\%20Generation\%20Capacity\%20Statement\%202015-2024.pdf.

European Commission (2008). "NACE Rev. 2-Statistical classification of economic activities in the European Community," Eurostat: Methodologies and Working papers. Luxembourg: Office for Official Publications of the European Communities.

European Commission (2014). "Energy Economic Developments in Europe," The European Economy series.

European Parliament and Council. (2009). "Directive 2009/28/EC of the European Parliament and of the Council of 23 April 2009 on the promotion of the use of energy from renewable sources and amending and subsequently repealing Directives 2001/77/EC and 2003/30/EC." Available: http://data.europa.eu/eli/dir/2009/28/oj.

Eurostat. 2015. "Gross electricity generation by fuel, GWh, EU-28, 1990-2013," [Online]. Available: http://ec.europa.eu/ eurostat/statistics-explained/index.php/File:T1Gross_electricity_generation_by_fuel,_GWh,_EU-28,_1990-2013.png [Accessed 22 October, 2015.

Haas, R., C. Panzer, G. Resch, M. Ragwitz, G. Reece, and A. Held (2011). "A historical review of promotion strategies for electricity from renewable energy sources in EU countries," Renewable and Sustainable Energy Reviews 15(2): 10031034.

IEA. (2014). "Medium-Term Renewable Energy Market Report 2014: Market Analysis and Forecasts to 2020.” Available: https://www.iea.org/Textbase/npsum/MTrenew2014sum.pdf.

Inglesi-Lotz, R. (2016). "The impact of renewable energy consumption to economic growth: A panel data application," Energy Economics 53: 58-63. https://doi.org/10.1016/j.eneco.2015.01.003.

Kapetanios, G., M. H. Pesaran, and T. Yamagata (2011). "Panels with Nonstationary Multifactor Error Structures," Journal of Econometrics 160(2): 326-348. https://doi.org/10.1016/j.jeconom.2010.10.001.

Kula, F. (2014). "The Long-run Relationship Between Renewable Electricity Consumption and GDP: Evidence From Panel Data," Energy Sources, Part B: Economics, Planning, and Policy 9(2): 156-160. https://doi.org/10.1080/ 15567249.2010.481655.

Lehr, U., C. Lutz, and D. Edler (2012). "Green jobs? Economic impacts of renewable energy in Germany,” Energy Policy 47: 358-364. https://doi.org/10.1016/j.enpol.2012.04.076.

Liebreich, M. (2013). "Keynote presentation: Bloomberg New Energy Finance Summit," Bloomberg New Energy Finance Summit [Online]. Available: http://about.bnef.com/category/presentations/.

Menegaki, A. N. (2011). "Growth and renewable energy in Europe: A random effect model with evidence for neutrality hypothesis," Energy Economics 33(2): 257-263. https://doi.org/10.1016/j.eneco.2010.10.004.

Ohler, A. I. and I. Fetters (2014). "The causal relationship between renewable electricity generation and GDP growth: A study of energy sources," Energy Economics 43: 125-139. https://doi.org/10.1016/j.eneco.2014.02.009.

Pedroni, P. (1999). "Critical values for cointegration tests in heterogeneous panels with multiple regressors," Oxford Bulletin of Economics and Statistics 61: 653-670. https://doi.org/10.1111/1468-0084.61.s1.14.

Pesaran, M. H. (2006). "Estimation and Inference in Large Heterogeneous Panels with a Multifactor Error Structure," Econometrica 74(4): 967-1012. https://doi.org/10.1111/j.1468-0262.2006.00692.x.

Pesaran, M. H. (2007). "A simple panel unit root test in the presence of cross section dependence," Journal of Applied Econometrics 22: 265-312. https://doi.org/10.1002/jae.951.

Pesaran, M. H. and R. P. Smith (1995). "Estimating Long-Run Relationships from Dynamic Heterogeneous Panels," Journal of Econometrics 68(1): 79-113. https://doi.org/10.1016/0304-4076(94)01644-F.

Ragwitz, M., W. Schade, B. Breitschopf, R. Walz, N. Helfrich, M. Rathmann, G. Resch, C. Panzer, T. Faber, R. Haas, C. Nathani, M. Holzhey, I. Konstantinaviciute, P. Zagamé, A. Fougeyrollas, and B. Le Hir (2009). "EmployRES: The impact 
of renewable energy policy on economic growth and employment in the European Union." Available: http:// www.ecofys.com/files/files/2009_employ_res_report.pdf.

Sadorsky, P. (2009a). "Renewable energy consumption and income in emerging economies," Energy Policy 37(10): 40214028. https://doi.org/10.1016/j.enpol.2009.05.003.

Sadorsky, P. (2009b). "Renewable energy consumption, $\mathrm{CO}_{2}$ emissions and oil prices in the $\mathrm{G} 7$ countries," Energy Economics 31(3): 456-462. https://doi.org/10.1016/j.eneco.2008.12.010.

Salim, R. A., K. Hassan, and S. Shafiei (2014). "Renewable and non-renewable energy consumption and economic activities: Further evidence from OECD countries," Energy Economics 44: 350-360. https://doi.org/10.1016/j.eneco.2014.05.001.

Sebri, M. (2015). "Use renewables to be cleaner: Meta-analysis of the renewable energy consumption-economic growth nexus," Renewable and Sustainable Energy Reviews 42: 657-665. https://doi.org/10.1016/j.rser.2014.10.042.

The Economist. (2010). "The global revival of industrial policy: Picking winners, saving losers," August 7th. Available: http://www.economist.com/node/16741043.

Ucan, O., E. Aricioglu, F. and M. Yucel (2014). "Energy Consumption and Economic Growth Nexus: Evidence from Developed Countries in Europe," International Journal of Energy Economics and Policy 4(3): 411-419.

Wagner, G., T. Kåberger, S. Olai, M. Oppenheimer, K. Rittenhouse, and T. Sterner (2015). "Energy policy: Push renewables to spur carbon pricing," Nature 525(7567): 27-29. https://doi.org/10.1038/525027a. 


\section{APPENDIX}

Figure A: Experience Curves of Solar and Wind Power Generation

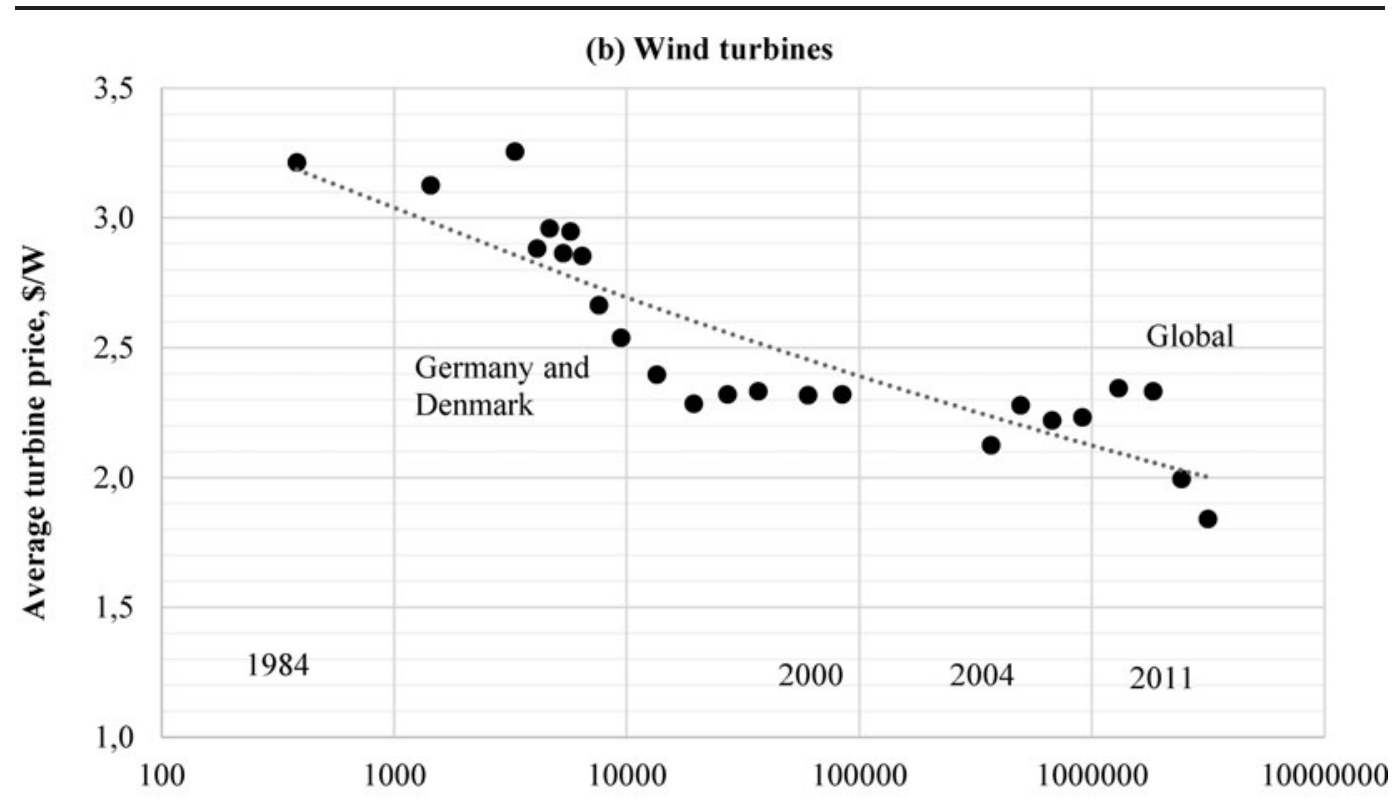

Cumulative capacity, MW

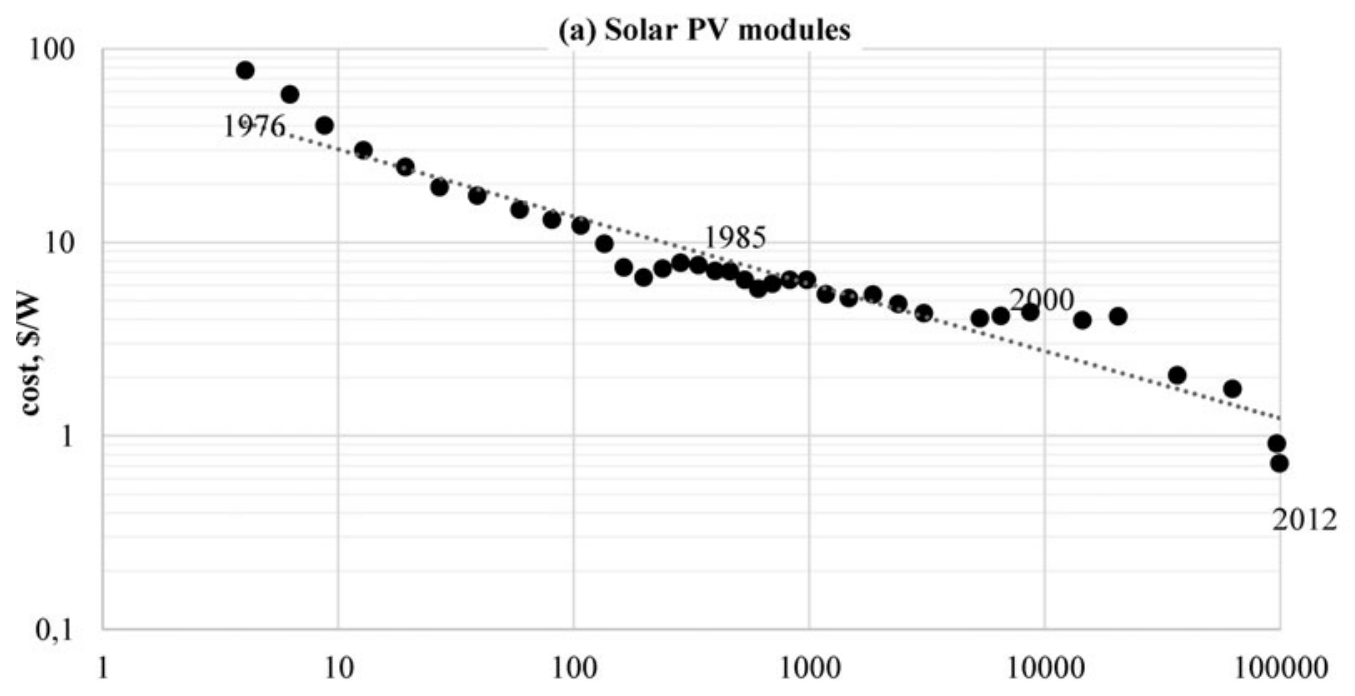

Cumulative capacity, MW

Source: Adapted from Liebreich (2013). 
Table A1: Unit Root Test for Each of the Series at the GDP (total economy), Manufacturing and Machinery Levels of Data Aggregation

\begin{tabular}{|c|c|c|c|c|}
\hline \multicolumn{5}{|c|}{ GDP level } \\
\hline & \multicolumn{3}{|c|}{ CIPS test No Trend } & \multirow{2}{*}{$\begin{array}{c}\text { CIPS test With Trend } \\
\text { Test Stats }\end{array}$} \\
\hline & Lags & Test Stats & Lags & \\
\hline $\ln Y$ & 2 & $\begin{array}{c}1.711 \\
(0.956)\end{array}$ & 2 & $\begin{array}{c}6.230 \\
(1.000)\end{array}$ \\
\hline$\Delta \ln Y$ & 0 & $\begin{array}{l}-5.825 \\
(0.000)\end{array}$ & 0 & $\begin{array}{l}-4.917 \\
(0.000)\end{array}$ \\
\hline $\ln K$ & 2 & $\begin{array}{c}3.380 \\
(1.000)\end{array}$ & 2 & $\begin{array}{c}1.780 \\
(0.962)\end{array}$ \\
\hline$\Delta \ln \mathrm{K}$ & 0 & $\begin{array}{l}-6.307 \\
(0.000)\end{array}$ & 0 & $\begin{array}{l}-5.448 \\
(0.000)\end{array}$ \\
\hline $\ln L$ & 2 & $\begin{array}{c}2.831 \\
(0.998)\end{array}$ & 2 & $\begin{array}{c}1.956 \\
(0.975)\end{array}$ \\
\hline$\Delta \operatorname{lnL}$ & 0 & $\begin{array}{l}-3.524 \\
(0.000)\end{array}$ & 0 & $\begin{array}{l}-3.210 \\
(0.001)\end{array}$ \\
\hline $\operatorname{lnEC}$ & 2 & $\begin{array}{l}-4.002 \\
(0.000)\end{array}$ & 2 & $\begin{array}{l}-2.117 \\
(0.017)\end{array}$ \\
\hline$\Delta \operatorname{lnEC}$ & 0 & $\begin{array}{c}-11.562 \\
(0.000)\end{array}$ & 0 & $\begin{array}{c}-10.124 \\
(0.000)\end{array}$ \\
\hline $\operatorname{lnSOL}$ & 2 & $\begin{array}{c}0.591 \\
(0.723)\end{array}$ & 2 & $\begin{array}{c}1.807 \\
(0.965)\end{array}$ \\
\hline$\Delta \operatorname{lnSOL}$ & 0 & $\begin{array}{l}-5.332 \\
(0.000)\end{array}$ & 0 & $\begin{array}{l}-3.463 \\
(0.000)\end{array}$ \\
\hline $\operatorname{lnWND}$ & 2 & $\begin{array}{l}-1.199 \\
(0.115)\end{array}$ & 2 & $\begin{array}{c}1.665 \\
(0.952)\end{array}$ \\
\hline$\Delta \operatorname{lnWND}$ & 0 & $\begin{array}{l}-8.922 \\
(0.000)\end{array}$ & 0 & $\begin{array}{l}-7.972 \\
(0.000)\end{array}$ \\
\hline
\end{tabular}

\begin{tabular}{|c|c|c|c|c|}
\hline \multicolumn{5}{|c|}{ Manufacturing level } \\
\hline & \multicolumn{3}{|c|}{ CIPS test No Trend } & \multirow{2}{*}{$\frac{\text { CIPS test With Trend }}{\text { Test Stats }}$} \\
\hline & Lags & Test Stats & Lags & \\
\hline $\ln Y$ & 2 & $\begin{array}{l}31.665 \\
(0.383)\end{array}$ & 2 & $\begin{array}{l}14.977 \\
(0.990)\end{array}$ \\
\hline$\Delta \ln Y$ & 0 & $\begin{array}{l}-7.188 \\
(0.000)\end{array}$ & 0 & $\begin{array}{l}-7.231 \\
(0.000)\end{array}$ \\
\hline $\ln K$ & 2 & $\begin{array}{c}0.899 \\
(0.816)\end{array}$ & 2 & $\begin{array}{c}2.549 \\
(0.995)\end{array}$ \\
\hline$\Delta \operatorname{lnK}$ & 0 & $\begin{array}{c}-10.881 \\
(0.000)\end{array}$ & 0 & $\begin{array}{l}-9.085 \\
(0.000)\end{array}$ \\
\hline $\operatorname{lnL}$ & 2 & $\begin{array}{l}4.197 \\
(1.000)\end{array}$ & 2 & $\begin{array}{l}-0.184 \\
(0.427)\end{array}$ \\
\hline$\Delta \operatorname{lnL}$ & 0 & $\begin{array}{l}-0.886 \\
(0.188)\end{array}$ & 0 & $\begin{array}{l}-0.689 \\
(0.246)\end{array}$ \\
\hline $\operatorname{lnEC}$ & 2 & $\begin{array}{c}3.308 \\
(1.000)\end{array}$ & 2 & $\begin{array}{c}1.799 \\
(0.964)\end{array}$ \\
\hline$\Delta \operatorname{lnEC}$ & 0 & $\begin{array}{l}-11.485 \\
(0.000)\end{array}$ & 0 & $\begin{array}{c}-11.466 \\
(0.000)\end{array}$ \\
\hline $\operatorname{lnSOL}$ & 2 & $\begin{array}{c}0.855 \\
(0.804)\end{array}$ & 2 & $\begin{array}{c}2.565 \\
(0.995)\end{array}$ \\
\hline$\Delta \operatorname{lnSOL}$ & 0 & $\begin{array}{l}-3.859 \\
(0.000)\end{array}$ & 0 & $\begin{array}{l}-2.275 \\
(0.011)\end{array}$ \\
\hline $\operatorname{lnWND}$ & 2 & $\begin{array}{l}-1.027 \\
(0.152)\end{array}$ & 2 & $\begin{array}{l}1.445 \\
(0.926)\end{array}$ \\
\hline$\Delta \operatorname{lnWND}$ & 0 & $\begin{array}{l}-8.578 \\
(0.000)\end{array}$ & 0 & $\begin{array}{l}-7.790 \\
(0.000)\end{array}$ \\
\hline
\end{tabular}


Table A1: Unit Root Test for Each of the Series at the GDP (total economy), Manufacturing and Machinery Levels of Data Aggregation (continued)

\begin{tabular}{|c|c|c|c|c|}
\hline \multicolumn{5}{|c|}{ Machinery level } \\
\hline & \multicolumn{3}{|c|}{ CIPS test No Trend } & \multirow{2}{*}{$\frac{\text { CIPS test With Trend }}{\text { Test Stats }}$} \\
\hline & Lags & Test Stats & Lags & \\
\hline $\ln Y$ & 2 & $\begin{array}{l}-0.994 \\
(0.160)\end{array}$ & 2 & $\begin{array}{l}-0.339 \\
(0.367)\end{array}$ \\
\hline$\Delta \ln Y$ & 0 & $\begin{array}{l}-6.256 \\
(0.000)\end{array}$ & 0 & $\begin{array}{l}-6.126 \\
(0.000)\end{array}$ \\
\hline $\ln K$ & 2 & $\begin{array}{c}3.095 \\
(0.999)\end{array}$ & 2 & $\begin{array}{l}24.198 \\
(1.000)\end{array}$ \\
\hline$\Delta \ln K$ & 0 & $\begin{array}{l}-9.447 \\
(0.000)\end{array}$ & 0 & $\begin{array}{l}-8.540 \\
(0.000)\end{array}$ \\
\hline $\operatorname{lnL}$ & 2 & $\begin{array}{c}2.736 \\
(0.997)\end{array}$ & 2 & $\begin{array}{c}4.792 \\
(1.000)\end{array}$ \\
\hline$\Delta \operatorname{lnL}$ & 0 & $\begin{array}{l}-5.907 \\
(0.000)\end{array}$ & 0 & $\begin{array}{l}-5.096 \\
(0.000)\end{array}$ \\
\hline $\operatorname{lnEC}$ & 2 & $\begin{array}{c}2.199 \\
(0.986)\end{array}$ & 2 & $\begin{array}{c}5.030 \\
(1.000)\end{array}$ \\
\hline$\Delta \operatorname{lnEC}$ & 0 & $\begin{array}{l}-9.935 \\
(0.000)\end{array}$ & 0 & $\begin{array}{c}-8.709 \\
(0.000)\end{array}$ \\
\hline $\operatorname{lnSOL}$ & 2 & $\begin{array}{c}0.855 \\
(0.804)\end{array}$ & 2 & $\begin{array}{c}2.565 \\
(0.995)\end{array}$ \\
\hline$\Delta \operatorname{lnSOL}$ & 0 & $\begin{array}{l}-3.859 \\
(0.000)\end{array}$ & 0 & $\begin{array}{l}-2.275 \\
(0.011)\end{array}$ \\
\hline $\operatorname{lnWND}$ & 2 & $\begin{array}{l}-1.027 \\
(0.152)\end{array}$ & 2 & $\begin{array}{c}1.445 \\
(0.926)\end{array}$ \\
\hline$\Delta \operatorname{lnWND}$ & 0 & $\begin{array}{l}-8.578 \\
(0.000)\end{array}$ & 0 & $\begin{array}{l}-7.790 \\
(0.000)\end{array}$ \\
\hline
\end{tabular}

The null hypothesis is that of a unit root, the Pesaran (2007) CIPS test allows for crosssectional dependency in the unit root testing procedure. The lag length is chosen base on AIC. The first difference (change) is denoted by $\Delta$ and the numbers in parenthesis are the $P$-values for the unit root test statistic. 
Table A2: Pedroni Cointegration Test for the Longrun Model for Each of the Three Levels of Data Aggregation

\begin{tabular}{lcc}
\hline & GDP level & \\
\hline Test Stats & Panel & Group \\
\hline V & -0.348 & $\cdot$ \\
Rho & 3.705 & 4.983 \\
T & -0.184 & -2.314 \\
Adf & 6.145 & 4.699 \\
\hline & Manufacturing & \\
\hline Test Stats & Panel & Group \\
\hline V & -0.310 & $\cdot$ \\
Rho & 2.675 & 4.388 \\
T & -4.060 & -4.145 \\
Adf & 5.692 & 6.653 \\
\hline & Machinery & \\
\hline Test Stats & Panel & Group \\
\hline V & -1.245 & $\cdot$ \\
Rho & 1.985 & -4.017 \\
T & -4.381 & -2.650 \\
Adf & -3.308 & \\
\hline
\end{tabular}

All test statistics are distributed $\mathrm{N}(0,1)$, under a null of no cointegration, and diverge to negative infinity.

\begin{tabular}{lc} 
Table A3: $\begin{array}{c}\text { Dynamic OLS Estimates } \\
\text { for Long-run Model for } \\
\text { Capacity }\end{array}$ \\
\hline \multicolumn{2}{c}{ RES Capacity } \\
\hline Lnk & $0.927^{* * *}$ \\
& $(0.056)$ \\
Lnl & -0.016 \\
& $(0.136)$ \\
Lnec & $0.148^{* * *}$ \\
& $(0.005)$ \\
Lnsol & $-0.027^{* * *}$ \\
& $(0.004)$ \\
Lnwnd & -0.004 \\
& $(0.006)$ \\
Lnsolproduction & \\
Lnwndproduction & \\
$N$ & 152
\end{tabular}

$* p<0.10, * * p<0.05, * * * p<0.01$, Standard errors in parentheses. The optimal lag of one is selected for both lead and lag based on AIC. 